\title{
New insights into pathogenesis point to HIV-1 Tat as a key vaccine target
}

\author{
Barbara Ensoli ${ }^{1}$ (1) Sonia Moretti ${ }^{1}$ - Alessandra Borsetti ${ }^{1} \cdot$ Maria Teresa Maggiorella $^{1} \cdot$ Stefano Buttò ${ }^{1}$. \\ Orietta Picconi ${ }^{1} \cdot$ Antonella Tripiciano $^{1} \cdot$ Cecilia Sgadari $^{1} \cdot$ Paolo Monini $^{1} \cdot$ Aurelio Cafaro $^{1}$
}

Received: 14 January 2021 / Accepted: 9 May 2021 / Published online: 14 August 2021

(C) The Author(s), under exclusive licence to Springer-Verlag GmbH Austria, part of Springer Nature 2021

\begin{abstract}
Despite over 30 years of enormous effort and progress in the field, no preventative and/or therapeutic vaccines against human immunodeficiency virus (HIV) are available. Here, we briefly summarize the vaccine strategies and vaccine candidates that in recent years advanced to efficacy trials with mostly unsatisfactory results. Next, we discuss a novel and somewhat contrarian approach based on biological and epidemiological evidence, which led us to choose the HIV protein Tat for the development of preventive and therapeutic HIV vaccines. Toward this goal, we review here the role of Tat in the virus life cycle as well as experimental and epidemiological evidence supporting its key role in the natural history of HIV infection and comorbidities. We then discuss the preclinical and clinical development of a Tat therapeutic vaccine, which, by improving the functionality and homeostasis of the immune system and by reducing the viral reservoir in virologically suppressed vaccinees, helps to establish key determinants for intensification of combination antiretroviral therapy (cART) and a functional cure. Future developments and potential applications of the Tat therapeutic vaccine are also discussed, as well as the rationale for its use in preventative strategies. We hope this contribution will lead to a reconsideration of the current paradigms for the development of HIV/AIDS vaccines, with a focus on targeting of viral proteins with key roles in HIV pathogenesis.
\end{abstract}

\section{Introduction}

\section{Exploring vaccine development strategies and predicting vaccine efficacy}

The human immunodeficiency virus (HIV)/acquired immunodeficiency syndrome (AIDS) epidemic is still a major global health challenge, with 38.0 million people living

Handling Editor: Marc H. V. Van Regenmortel.

Barbara Ensoli

barbara.ensoli@iss.it

Sonia Moretti

sonia.moretti@iss.it

Alessandra Borsetti

alessandra.borsetti@iss.it

Maria Teresa Maggiorella

mariateresa.maggiorella@iss.it

Stefano Buttò

stefano.butto@iss.it

Orietta Picconi

orietta.picconi@iss.it with HIV (PLWH) in 2019, and 1.7 million newly infected (https://www.unaids.org/en/resources/presscentre/pressrelea seandstatementarchive/2020/july/20200706_global-aidsreport). Thus, there is an urgent need to implement effective strategies to prevent and cure HIV infection and reduce virus transmission [1].

Although combination antiretroviral therapy (cART) is effective in suppressing the virus and reducing mortality, it does not eradicate HIV, which invariably rebounds upon suspension of treatment due to virus release by a small pool of

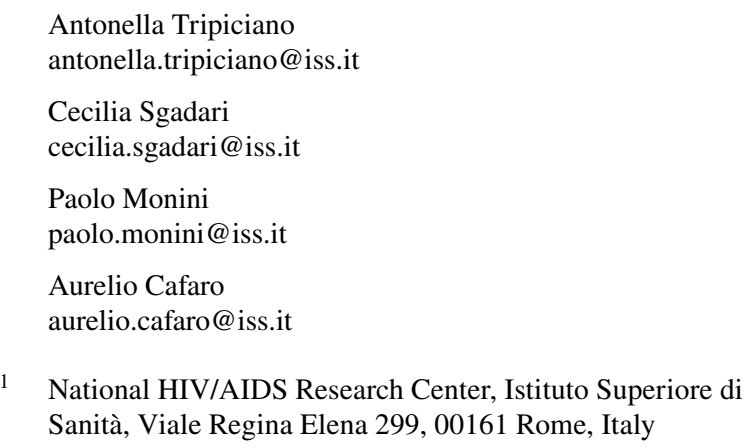

1 National HIV/AIDS Research Center, Istituto Superiore di Sanità, Viale Regina Elena 299, 00161 Rome, Italy 
long-lived cells harboring latent provirus, which are insensitive to cART and invisible to the immune system [2]. This hampers cART effectiveness in containing HIV transmission and spread [3].

Furthermore, despite great efforts and major advancements in our understanding of HIV pathogenesis and in vaccine development, effective vaccines against HIV/AIDS are still lacking.

The challenges for developing a vaccine against HIV stem from (i) the high rate of intra- and inter-individual HIV genetic evolution, leading to the unceasing emergence of new (escape) variants, (ii) the failure to identify strong and unequivocal correlates of protection in studies of natural infection as well as in vaccine studies, and (iii) the knowledge gap regarding the degree of protection conferred by the immune response to antigenic epitopes present in the transmitted/founder viruses versus viral variants emerging during chronic infection.

The first vaccine candidates largely focused on the glycoproteins of the virus envelope, which mediate the attachment and entry of HIV into the cell (gp120 or gp160) [4, 5]. AIDSVAX was the first of the Env-based vaccines to be tested in efficacy trials (VAX 003, NCT 00006327 and VAX 004, NCT 00002441). However, AIDSVAX failed to induce a protective, neutralizing humoral response, most likely due to the high variability of Env in the circulating virus variants $[6,7]$. These failures shifted the focus to cell-mediated immunity, owing to an accumulating body of evidence indicating a major role for $\mathrm{CD}^{+} \mathrm{T}$ cells in controlling HIV infection [8-12]. Vaccines aimed at inducing effective cellular responses were based on live recombinant viral vectors, mainly pox and adenovirus vectors, and/or DNA consisting of the gag, pol, and nef genes from clade B or clade C HIV, with or without Env [13, 14]. Although all approaches induced measurable cell-mediated immune responses, they had to be halted due to the greater number of HIV-1 infections occurring in vaccinees as compared to placebo, as observed in the STEP (HVTN 502, NCT00095576) and Phambili (HVTN 503, NCT 00413725) trials, or they did not show efficacy (HVTN 505, NCT00865566) [4, 15-19]. The vectors used to deliver the HIV proteins are believed to have contributed to vaccine failure [20].

Expectations were then raised by the RV144 (NCT00223080) trial utilizing a recombinant canarypox vector expressing Env from clade E and Gag and the HIV protease from clade B HIV (the ALVAC-HIV vCP1521 vaccine antigen component), followed by a boost with an alum-adjuvanted subunit HIV gp120 from clades B and E (the AIDSVAX B/E vaccine antigen component). The vaccine induced a humoral immune response against gp120 and antibody-dependent cellular cytotoxicity that was able to confer protection from infection in $31.2 \%$ of the vaccinated volunteers [21], leading to the design of the HVTN 702 trial (NCT 02968849) conducted in South Africa, which, however, did not show efficacy (https://www.niaid.nih.gov/ news-events/experimental-hiv-vaccine-regimen-ineffectivepreventing-hiv).

Concurrently, major efforts and resources were devoted to the isolation and characterization of broadly neutralizing antibodies (bNAbs) from infected patients [22]. It turned out that, in general, bNAbs have a very uncommon structure, are often polyreactive and autoreactive, possibly the result of escape from immune selection of the B cell repertoire, as also suggested by the lack of germline precursors in the B cell repertoire [23]. Accordingly, immunogens structurally designed to optimally bind bNAbs failed to induce them in vivo [24-26]. These obstacles are so difficult to overcome [27] that the efficacy of bNAbs is presently being evaluated in passive immunization strategies [28].

More recently, a computational methodology was developed to generate polyvalent mosaic immunogens starting from the sequences of naturally occurring variants of common $\mathrm{T}$ cell epitopes that may ensure coverage of HIV diversity [29]. An example of this "mosaic" approach is the Ad26/ Ad26 plus gp 140 HIV-1 vaccine, which was recently shown to induce robust humoral and cellular immune responses in a phase $1 / 2$ a clinical trial, and it is being evaluated in a phase 2b efficacy study in sub-Saharan Africa (NCT03060629).

Efforts have also been directed to optimization of analysis of vaccine trial results with the aim of identifying correlates of protection. Among these, the COMPASS (Computerized Optimization Model for Predicting and Analyzing Support Scenarios) analysis, a bioinformatics tool to identify antigenspecific $\mathrm{T}$ cell responses and subsets, was recently used to investigate vaccine-induced immune responses leading to the identification of new "correlates of protection/immunity" previously missed in the RV 144 HIV vaccine efficacy trial [30, 31].

Failures in HIV preventative and therapeutic vaccine strategies have led us to focus on alternative strategies using a "pathogenetic" approach aimed at targeting the HIV Tat protein, alone or combined with other HIV antigens, for eliciting protective immunity for preventative and therapeutic vaccination of untreated or cART-treated patients.

\section{Tat and HIV pathogenesis}

\section{Role of Tat in the virus life cycle}

\section{Tat-mediated effects on HIV-1 infectivity, replication, and transmission}

The HIV Tat protein is a potent transcriptional transactivator of virus gene expression that is essential for virus infectivity, replication, and transmission (Fig. 1). Tat is incorporated 


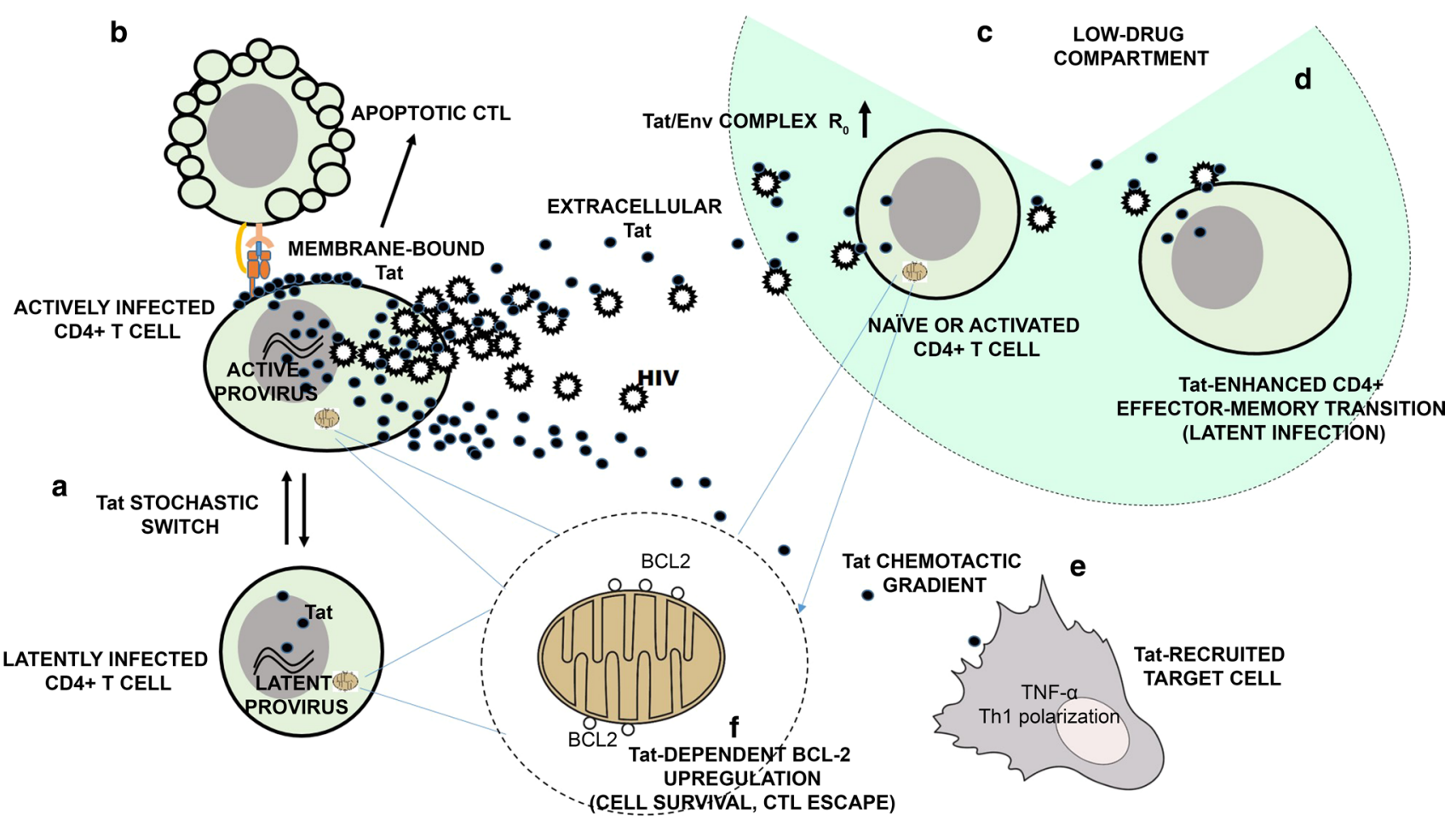

Fig. 1 Roles of extracellular Tat in HIV in virus life cycle and in the latent virus reservoir. A Stochastic oscillations of HIV-1 Tat protein expression (the Tat stochastic switch) determine the fate of HIV infection [40]; B Membrane-bond extracellular Tat induces CTL apoptosis [64]; C Extracellular Tat binds Env to form a HIV entry complex [35] that increases virus infectivity and the HIV basic reproduction number $\left(\mathrm{R}_{0}\right)$, thus increasing the chances of infection in tissue compartments with low-drug penetration; at the same time, extracellular Tat induces in naïve CD4+ T cells a non-classical activation pathway rendering these cells susceptible to HIV infection [54];

into HIV-1 virions [32] to prime both endogenous (intravirion) and post-entry reverse transcription [33], to activate virus gene expression, and to form a complex with HIV-1 Env to enhance virus entry and spread $[34,35]$.

Tat is expressed very early upon infection, even prior to virus integration [36], most likely to ensure that the transcriptional activity of the incoming virus can cross the extinction threshold. Tat expression, in fact, enhances both transcription initiation, which is mediated by its interaction with SP1 elements in the HIV-1 transcriptional promoter [37, 38], and transcription elongation, which involves Tatmediated recruitment of positive transcription elongation factor $\mathrm{b}(\mathrm{P}-\mathrm{TEFb})$ to the transactivation responsive region (TAR) of the nascent RNA [39]. By these means, Tat increases viral transcription by 100 -fold and establishes a strong positive transcriptional feedback loop at the HIV-1 long terminal repeat (LTR) [40, 41]. Notably, the early expression of Tat appears to enhance, rather than stabilize,
D Extracellular Tat enhances the expansion and differentiation of naïve CD4+ T cells into effector-memory cells [75], thus increasing the number of cells transitioning from the activated to the resting state, a cell state that favors latent infection [94]; E Extracellular Tat forms chemotactic gradients [46; 48, 49] recruiting monocytes/ macrophages and dendritic cells to the site of infection (51), induces the release of pro-inflammatory cytokines [59-63] and the maturation of dendritic cells with a Th-1 polarization [52]; F Tat upregulates BCL2 in CD4+ T cells, leading to increased reservoir cell survival [93] while rendering these cells resistant to CTL killing [94]

basal transcriptional fluctuations that occur naturally at the HIV LTR. As a consequence, Tat expression itself is driven into amplified stochastic oscillations around the extinction threshold [40, 41]. As described in the next section, this pattern of Tat expression plays a major role in determining whether infected cells enter a state of active replication or latency $[40,41]$. In addition to these activities, Tat expression downregulates cell membrane expression of major histocompatibility complex (MHC) class I [42] and II [43] surface molecules, damping cell-mediated adaptive immunity against HIV. Moreover, in infected dendritic cells (DCs), Tat induces the expression of several chemokines, including interferon-gamma-induced protein 10 (IP-10, CXCL10), human monokine induced by interferon gamma (huMIG, CXCL9), and monocyte chemotactic protein 2 (MCP-2, CCL8), attracting activated $\mathrm{T}$ cells and macrophages to the sites of infection, thus facilitating the dissemination of HIV infection [44]. 
Role of extracellular Tat in HIV-1 infectivity and virus spread

A large proportion of the Tat protein produced by the infected cell is released in the absence of cell death or cell permeability changes in the extracellular milieu [45-47] to generate a local reservoir of extracellular Tat, which plays a key role in the establishment and propagation of HIV infection. In fact, once released, Tat binds through its basic region to heparan sulfate proteoglycans (HSPG) present in the extracellular matrix [45, 46, 48, 49], generating longlasting chemotactic gradients that attract HIV-1 target cells, particularly, activated endothelial cells and monocytes/macrophages, to the sites of infection $[50,51]$. In addition, extracellular Tat enters dendritic cells [52] and activated endothelial cells [53] very efficiently and, to a lesser extent, $\mathrm{CD} 4^{+} \mathrm{T}$ cells [54], activating the expression of genes favoring HIV dissemination. In particular, in naïve $\mathrm{CD}^{+} \mathrm{T}$ cells, Tat upregulates the expression of the $\mathrm{HIV}-1$ co-receptors $\mathrm{C}-\mathrm{X}-\mathrm{C}$ motif chemokine receptor 4 (CXCR4) and $\mathrm{C}-\mathrm{C}$ chemokine receptor type 5 (CCR5) [55], while antagonizing CXCR4 [56], thus increasing the susceptibility of resting $\mathrm{CD}^{+} \mathrm{T}$ cells to infection by R5-tropic HIV-1 strains. Furthermore, extracellular Tat induces a non-classical activation pathway in naïve $\mathrm{CD}^{+} \mathrm{T}$ cells, rendering them susceptible to productive infection $[54,57]$. Notably, extracellular Tat binds trimeric HIV-1 Env, forming a cell entry complex (the Tat/Env complex) that targets the RGD-binding integrins expressed at high levels by dendritic cells, enhancing the infection of these cells [34, 35]. Furthermore, extracellular Tat induces dendritic cells to mature to a $\mathrm{T}$ helper (Th)-1-polarizing phenotype [58] and stimulates the production and release of inflammatory cytokines by various cell types [59-63]. Of note, inflammatory cytokines activate endothelial cells and render them susceptible to Tat entry and permissive to productive HIV infection [53]. In addition, extracellular Tat bound to the HSPG of the infected cell membrane triggers the apoptotic death of engaged $\mathrm{CD} 8^{+} \mathrm{T}$ cell effectors [64]. Thus, extracellular Tat contributes to modeling a tissue microenvironment favoring the recruitment, infection, and immune escape of HIV-1 target cells. All of these activities of extracellular Tat contribute to ensuring that the basic reproduction number $\left(\mathrm{R}_{0}\right)$ of HIV remains $>1$ both upon virus acquisition at the portal of entry and during chronic infection.

\section{Role of the Tat feedback transcriptional loop in the "choice" between latent and active infection}

HIV-1 infection is characterized by the early establishment of a self-renewing, large pool of short-lived, actively infected cells producing viral progeny. However, concomitant latent infection occurs in a minority of cells that show prolonged longevity and are maintained for a long period of time. As described previously, the choice between productive and latent infection of $\mathrm{CD} 4^{+} \mathrm{T}$ cells appears to be determined by stochastic oscillations in the expression levels of Tat around the threshold of viral transcriptional extinction [41]. This modality of Tat expression (the "Tat stochastic switch") (Fig. 1) appears to operate irrespectively of the state of cell activation [41]. Nevertheless, the activation or deactivation of the HIV-1 transcriptional promoter by environmental or epigenetic stimuli can increase or decrease the probability ratio between latent and active infection [41]. The Tat stochastic switch likely explains several characteristic features of HIV infection both in vitro and in clinical studies. In particular: (i) distinct pools of latently and productively infected cells are simultaneously established upon experimental infection of activated or resting $\mathrm{CD} 4^{+} \mathrm{T}$ cells [65-67]; (ii) clonal $\mathrm{CD} 4^{+} \mathrm{T}$ cell populations harboring the same provirus at the same integration site show a 'bifurcating' expression pattern, where HIV expression is high in some cells and low in others [40]; (iii) polyclonal TCR stimulators stochastically reactivate HIV in only a small number of cells in the latently infected pool present in cultures of $\mathrm{CD}^{+} \mathrm{T}$ cells isolated from HIV-infected patients [68, 69]; (iv) a spontaneous fluctuation between a latent and productive infection phenotype is observed in clonal cultures of infected $\mathrm{CD} 4^{+}$ $\mathrm{T}$ cell lines [40]; (v) virus rebound in patients undergoing analytical treatment interruption follows a stochastic, exponential distribution [70]; (vi) the "shock and kill" strategy to cure HIV, based on the use of HIV latency-reversing agents believed to deterministically reactivate latent HIV, has failed to reduce the HIV reservoirs [71]; and (vii) HIV reactivation in latently infected $\mathrm{CD} 4^{+} \mathrm{T}$ cells is virtually abolished by treatment with compounds that block the interaction of Tat with TAR, a finding that has led to the development of strategies to permanently shut off HIV transcription (the "block and lock" strategy) [72].

\section{Role of extracellular Tat in the dynamics of latent HIV reservoirs}

The small pool of long-lived cells harboring latent HIV persists indefinitely in infected individuals despite cART. Sporadic reactivation of latent provirus results in waves of virus production that, although it may not succeed in infecting other cells due to antiretroviral treatment, can give rise to intermittent low-level viremia that persists even after years of treatment [73]; if cART is suspended, low-level viremia leads to virus rebound [74]. Although several cell types can harbor latent or silent HIV, resting naïve and memory $\mathrm{CD} 4^{+} \mathrm{T}$ cells constitute the most prominent HIV reservoir [73]. Considering the capability of extracellular Tat to target and enter $\mathrm{CD} 4^{+} \mathrm{T}$ cells [54], to stimulate the expression of host cell genes [54, $55,75]$, and to reactivate latent provirus [40, 45, 76], it 
can be speculated that extracellular Tat plays a prominent role in the dynamics of HIV reservoirs. This conclusion is supported by the faster kinetics of proviral DNA decay observed in individuals on long-term cART immunized with a Tat vaccine [77, 78], suggesting that immunity against extracellular Tat, the vaccine target, may destabilize the HIV reservoirs. The following lines of evidence point to the possible mechanism(s) underlying this effect of Tat immunization.

Despite lack of evidence of virus evolution during long-term cART [79-84], indirect evidence indicates that ongoing cycles of virus replication may indeed occur in low-drug lymphoid tissue compartments, replenishing the HIV reservoirs [85-89]. However, HIV reproduction in these infection niches would be prone to extinction due to the reduction of $\mathrm{R}_{0}$ caused by the suboptimal drug levels of the microenvironment. Hence, the enhancement of infectivity conferred to HIV by the Tat/Env complex, which appears to be particularly effective at a low multiplicity of infection [35], would conceivably be of key importance for virus reproduction in these tissues. Since anti-Tat Abs produced during natural infection or induced by Tat immunization neutralize the Tat/Env complex [35], these data suggest that immunization with Tat might blunt this potential pathway of reservoir replenishment. CD4 ${ }^{+}$ $\mathrm{T}$ cells undergoing the effector-to-memory transition may be pivotal in this context. These cells have been shown to be particularly susceptible to latent HIV infection due to the transient upregulation of the HIV co-receptor CCR5 and the concomitant downregulation of cellular and proviral gene expression [90]. Hence, activated CD4 ${ }^{+}$ $\mathrm{T}$ cells transitioning to the resting state represent a key target to enrich latent-HIV reproduction in compartments with suboptimal drug levels. Since extracellular Tat is known to enhance the expansion and differentiation of naïve $\mathrm{CD} 4^{+} \mathrm{T}$ cells towards the effector-memory phenotype [75], we speculate that immunization with Tat may decrease the density of transitioning cells in these tissue niches. Moreover, extracellular Tat delays Fas-mediated apoptosis in infected $\mathrm{CD} 4^{+} \mathrm{T}$ cells [91] and upregulates the anti-apoptotic gene B-cell lymphoma 2 (Bcl-2) in peripheral blood mononuclear cells (PBMCs) and $\mathrm{CD} 4^{+}$ $\mathrm{T}$ cells, as well as endothelial cells [92], promoting their survival [93]. Notably, recent findings indicate that Bcl-2 upregulation renders reservoir $\mathrm{CD} 4^{+} \mathrm{T}$ cells resistant to cytotoxic T lymphocyte (CTL) killing [94]. Thus, extracellular Tat may prolong the half-life of latently infected $\mathrm{CD} 4^{+} \mathrm{T}$ cells, which, conversely, would be decreased by anti-Tat Abs induced by Tat immunization. Finally, antiTat Abs would abrogate the capacity of cell-membranebound Tat to induce the apoptosis of $\mathrm{CD} 8^{+} \mathrm{T}$ cell effectors [64], restoring, at least in part, the effectiveness of cell-mediated immunity against the virus reservoirs.
Figure 1 summarizes the main pathways through which HIV-1 Tat regulates the virus life cycle and the genesis and maintenance of the virus reservoirs.

\section{Tat and comorbidities}

The experimental and epidemiological data reported above indicate that Tat is an optimal target for HIV cure and eradication strategies. However, a Tat-based therapeutic immunization may have other beneficial effects against HIV/AIDS, since in vitro and in vivo evidence indicates that HIV-1 Tat plays a role in the increased incidence and aggressiveness of several AIDS- and non-AIDS-defining comorbidities, including tumors and cardiovascular, renal, liver and neurological diseases. The development and progression of these comorbidities are attributed to the combined effects of reduced immune surveillance, immune activation, immune dysregulation, and viral coinfections (Epstein-Barr virus [EBV], human herpesvirus 8 [HHV-8], human papillomavirus [HPV], hepatitis $B$ virus, hepatitis $C$ virus) characterizing HIV infection [95].

Of note, the introduction of highly effective new antiretrovirals and new drug combinations capable of suppressing viral replication has greatly reduced the burden of most AIDS-related complications by restoring and preserving immune function from the decline associated with HIV infection, with a general increase in quality and expectancy of life [96]. However, since cART does not eliminate nonreplicating virus, life-long cART is essential for insuring viral suppression. Moreover, even under fully successful therapy, residual viral replication and/or gene transcription persist [97, 98], particularly in lymphoid tissues with suboptimal antiviral drug penetration $[89,99]$. As a result, chronic inflammation and immune dysregulation persist, leading to premature aging and a much higher incidence and mortality rate for chronic noninfectious comorbidities as compared to the general population, particularly in patients starting cART with very low $\mathrm{CD} 4^{+} \mathrm{T}$ cell counts or in those who are poorly compliant with therapy [96]. An increased life expectancy, longer exposure to risk factors, and drug toxicity also correlate with the appearance of non AIDS-related comorbidities. However, although cART reduces the risk for AIDS-defining comorbidities, including tumors and opportunistic infections, their incidence is still higher than in the general population and can also occur in patients responding to therapy $[96,100]$.

In this context, experimental evidence indicates that HIV-1 Tat may play a direct pathogenetic role in HIV-associated comorbidities by modulating the cellular pathways that lead to their development and/or progression. Although a comprehensive examination of these data is outside of the scope of this review, some of these direct effects are briefly described below and summarized in Table 1 . 
Table 1 Evidence indicating that the HIV-1 Tat protein is directly involved in the increased incidence and severity of comorbidities and coinfections affecting PLWH

Direct effects of Tat

References

AIDS-associated tumors

Kaposi's sarcoma

Proliferation, migration and invasion of KS cells

$[48,49,92,101-110]$

Recruitment of HHV-8-infected circulating KS cells; HHV-8 reactivation from latency; increase of tumor progression induced by HHV-8-encoded oncoproteins

Induction of inflammatory cytokines/adhesion marker expression in endothelial cells and KS cells

Induction of inflammatory cell adhesion and extravasation

Induction of angiogenesis and vascular permeability in synergy with bFGF or inflammatory cytokines, by activating MMPs and cell-cycle progression in endothelial cells

Cervical carcinoma

Increased survival by promoting Bcl-2 expression in endothelial cells

Disruption of epithelial tight junctions and HPV entry into epithelium by activation of integrin and MAPK signaling

Transactivation of the HPV long control region and increase of HPV-E7 expression

Lymphoproliferative disorders

Upregulation of HPV-E6 expression and decrease of p53 protein levels

Enhancement of EBV-driven B cell proliferation

Induction of mutagenic DNA repair h-polymerase

Repositioning of the MYC locus near the immunoglobulin heavy chain gene locus in B cells with increased risk of chromosomal translocation

High rate of mutation leading to $\mathrm{B}$ cell malignancies

Comorbidities

Cardiovascular diseases

Modulation of adhesion molecules expression, with increased vascular adhesion of monocytes and endothelial dysfunction associated with atherosclerosis, coronary artery disease, myocarditis, and hypertrophic cardiomyopathy

Decrease of endothelium-dependent vasorelaxation and endothelial NOS production in coronary arteries

Nephropathy

Increase of glomerular permeability by altering cytoskeleton organization and nephrin distribution in human podocytes

Renal expression of HIV genes, bFGF and VEGF-A

Osteoporosis

Reduced differentiation of bone marrow osteoblast precursor stem cells into osteoblastic cells

Upregulation of osteoclast bone resorption

Enhanced osteoclast differentiation

Enteropathy

Pro-oxidant and pro-apoptotic effects on colonic epithelial cells and consequent disruption of intestinal barrier integrity

Direct anti-proliferative effects on enterocytes, with intestinal mucosal atrophy

Increased excitability of the enteric nervous system

Pulmonary disease

Suppression of CFTR with alteration of mucociliary clearance

Release of reactive oxygen species and activation of platelet-derived growth factor with development of pulmonary hypertension

CNS neuropathy

Disruption of the blood-brain barrier and neuronal synapses

Increased expression of inducible NOS and NO release in astrocytes, microglia, and brain endothelial cells, with induction of oxidative stress, mitochondrial injury, and inflammation

Involvement in the development of HIV-1-associated neurocognitive disorders 
Table 1 (continued)

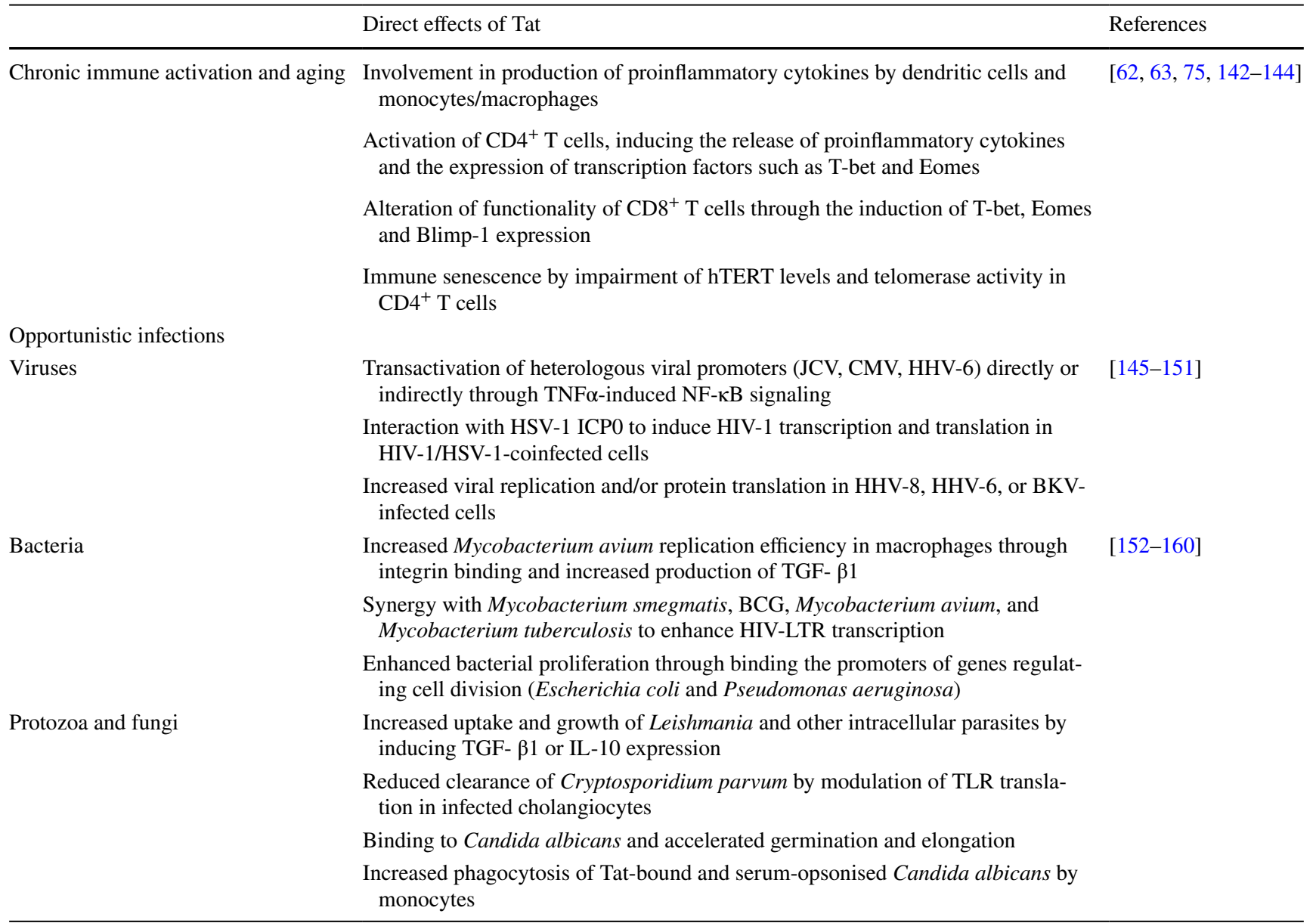

Abbreviations: KS, Kaposi's sarcoma; HHV, human herpes virus; bFGF, basic fibroblast growth factor; MMPs, matrix metalloproteinases; bcl-2, B-cell lymphoma 2; HPV, human papillomavirus; MAPK, mitogen-activated protein kinases; EBV, Epstein-Barr virus; JCV, John Cunningham virus; CMV, cytomegalovirus; TNF $\alpha$, tumor necrosis factor alpha; NF- $\mathrm{BB}$, nuclear factor kappa-light-chain-enhancer of activated B cells; HSV1, herpes simplex virus 1; BCG, bacillus Calmette-Guérin; TGF- $\beta 1$, transforming growth factor $\beta 1$; IL-10, interleukin 10; TLR, Toll-like receptor; VEGF-A, vascular endothelial growth factor A; NOS, nitric oxide synthase; NO, nitric oxide; HIV, human immunodeficiency virus; CFTR, cystic fibrosis transmembrane conductance regulator; T-bet, T-box expressed on T cells; Eomes, eomesodermin; hTERT, human telomerase reverse transcriptase

HIV-1 Tat has been implicated directly in the pathogenesis of AIDS-associated tumors, such as Kaposi's sarcoma (KS), cervical cancer, and lymphoproliferative disorders, while only indirect evidence is available for those tumors whose risk is only modestly increased during HIV infection, such as lung and liver cancer (non-AIDS-defining cancers). In particular, Tat promotes the migration, invasion, and proliferation of KS cells and activated endothelial cells $[48,49,92,101-106]$ (Table 1). This is due to the ability of Tat to mimic and/or enhance the effects of extracellular matrix molecules, which regulate and enhance the effects of angiogenic growth factors on endothelial cell growth and locomotion through RGD-binding integrins that function as Tat receptors [50, 101-103]. Tat also induces angiogenesis and vascular permeability in synergy with angiogenic factors or inflammatory cytokines by activating matrix metalloproteinases (MMPs) [92] and promotes the recruitment of HHV-8-infected circulating KS cells into tissues [103], triggers HHV-8 reactivation from latency, and accelerates tumor progression induced by HHV-8-encoded oncoproteins [107-110] (Table 1).

Moreover, among the various effects in the other AIDSassociated tumors, Tat can also interact with several oncogenes. For example, it upregulates HPV-E6 and -E7 oncoprotein activity in cervical cancer, thus increasing cell proliferation and survival and angiogenesis [111-116], and it promotes Myc repositioning near the immunoglobulin (Ig) heavy chain locus in normal B cells, thus increasing the risk of specific chromosomal translocations during lymphomagenesis [117-122] (Table 1). 
Individuals with HIV also have a disproportionate risk of various comorbidities to which the Tat protein appears to contribute. In particular, Tat plays an important role in HIVrelated cardiac dysfunction by modulating the expression of adhesion molecules on the endothelium and facilitating the adhesion of monocytes [123]. This leads to vascular inflammation and endothelial dysfunction, which is associated with the pathogenesis of cardiovascular complications affecting PLWH, including atherosclerosis, coronary artery disease, myocarditis, and hypertrophic cardiomyopathy [124-126] (Table 1). Tat may also contribute to functional alterations occurring in HIV-associated nephropathy by altering glomerular permeability and by inducing the redistribution and loss of nephrin in podocytes $[127,128]$ (Table 1). By interfering with osteoblastic differentiation and enhancing osteoclast differentiation, Tat also contributes to increased osteopenia/osteoporosis affecting PLWH [129-131] (Table 1). Tat also plays a key role in HIV-1-associated intestinal disorders, as it alters the expression of many genes regulating survival and growth of enterocytes and the excitability of the enteric nervous system, contributing to the gut dysfunction that has been described in HIV patients [132-134] (Table 1). Moreover, Tat may be implicated in pulmonary complications in PLWH by altering mucociliary clearance and contributing to the development of pulmonary hypertension [135-137] (Table 1). Tat is also known to induce neurotoxicity by disrupting the blood-brain barrier and neuronal synapses, promoting oxidative stress in astrocytes, microglia, and brain endothelial cells, and activating inflammation, thus contributing to the development of HIV-1-associated neurocognitive disorders [126, 128, 138-141] (Table 1). Finally, Tat is involved in overstimulation of the immune system and production of the high level of inflammatory responses seen in HIV-infected patients, contributing to the exacerbation of several immune dysfunctions observed during disease progression, such as chronic immune activation and premature aging [62, 63, 75, 142-144] (Table 1).

HIV-1 Tat has also been shown to interact with various opportunistic pathogens during AIDS progression, increasing the incidence and severity of infections. In this context, Tat can increase the transcription of the genomes of other viruses, such as John Cunningham virus (JCV) [145], cytomegalovirus (CMV) [145], and HHV-6 [146], either directly, by binding heterologous viral promoters, or indirectly, by activating the nuclear factor kappa-light-chain-enhancer of activated $B$ cells $(\mathrm{NF}-\mathrm{\kappa B})$ signaling pathway through its binding to the tumor necrosis factor alpha (TNF- $\alpha$ ) promoter (Table 1). Tat also modulates the transcription and translation of herpes simplex viruses, and of HHV-6 and HHV-8 [146-151] (Table 1), which are considered cofactors for the development of several tumors, including nodular sclerosis Hodgkin lymphoma, gastrointestinal cancer, glial tumors, and/or KS.
Moreover, via its RGD motif, Tat can bind integrins present on the surface of pathogens such as mycobacteria and fungi $[152,153]$ (Table 1). This binding increases mycobacterial replication efficiency and accelerates the germination and elongation of Candida albicans to form pseudohyphae, contributing to the increased severity of these opportunistic infections in HIV-infected patients [154-156]. In addition, HIV-1 Tat can cooperate with bacteria to synergistically enhance transcription from the HIV LTR and can regulate some bacterial gene expression and proliferation [157, 158] (Table 1). HIV-1 Tat has also been shown to interact with protozoa of the family Trypanosomatidae [159, 160]. It was reported to induce the uptake of Leishmania parasites and to increase their intracellular growth (Table 1). Thus, in HIV coinfections, Tat enhances infection and replication of both pathogens and HIV-1, further worsening the infectious burden in the host.

Taken together, all of these findings provide a strong rationale for targeting Tat in intervention strategies aimed at improving the clinical management and the quality of life of PLWH, even in the cART era.

\section{The Tat-based concept for HIV vaccine development}

\section{Regulation of immune responses by HIV Tat}

The biologically active Tat protein displays immunomodulatory features that make it an attractive antigen, alone or combined with other HIV proteins, for the design of new HIV vaccines [161-165]. In particular, native Tat protein is very efficiently taken up by monocyte-derived dendritic cells and, upon cellular entry, promotes DC maturation and activation, leading to a more efficient presentation of both allogeneic and exogenous antigens and resulting in an increased antigen-specific $\mathrm{T}$ cell response [52]. By modifying the catalytic subunit composition of the immunoproteasome, the Tat protein broadens epitope-specific CTL and Th- 1 immune responses to heterologous antigens [161-166]. Moreover, through its basic domain, Tat increases the surface expression of peptides complexed with MHC class I molecules [167], whereas dimerization promoted by the cysteine-rich region confers on Tat the capability to trigger strong immune response against itself as well as other antigens [168].

Taken together, these findings clearly demonstrate that Tat is not only an antigen but also a novel and potent immunoregulatory protein capable of promoting Th-1 responses and broadening the spectrum of epitopes recognized by $\mathrm{T}$ cells. This property may be important for the design of adjuvant-free Tat-based vaccines, or for using Tat as an immunoregulator to improve the efficacy of other vaccines. It is noteworthy that co-immunization with Env and Gag proteins 
together with Tat induces T-cell responses to all of these antigens, ruling out potential interference and providing evidence that a vaccine formulation containing Tat and other relevant HIV target proteins is feasible, and it may have the advantage of controlling virus replication at both the early and late stages of the infection [165]. The inherent ability of Tat to broaden the $\mathrm{T}$ cell repertoire may indeed be particularly relevant in vaccination strategies against other viral infections or tumors. In fact, it is widely held that increasing the size and broadening the diversity of $\mathrm{T}$ cell responses to a given antigen would increase the efficacy of a vaccine and reduce epitope mutation and CTL escape $[165,166]$. In this regard, vaccination with a live attenuated herpes simplex virus (HSV) vector expressing Tat increased memory CD8 ${ }^{+}$ $\mathrm{T}$ cell responses against epitopes present in subjects without recurrences, who were therefore called "asymptomatic", and it was considered protective, inducing anti-HSV $\operatorname{IgG} 2 \mathrm{a}$ (an indicator of a Th1-driven B cell response) and protecting mice from death after a lethal challenge with wild-type HSV [142, 169-171]. In particular, Tat increases in vitro and in vivo IFN- $\gamma$, granzyme B, and interleukin-2 (IL-2) release $[142,144]$, and in mice, injection with Tat increases the frequency of HSV1-specific effector memory CD ${ }^{+} \mathrm{T}$ cells [142], which are associated with asymptomatic HSV infection in humans [172]. Finally, Tat upregulates expression of T-box in T cells (T-bet), Eomes, B lymphocyte-induced maturation protein 1 (Blimp-1), and Bcl-2 in activated $\mathrm{CD}^{+}$ T cells [144], factors that are upregulated in HSV1-specific $\mathrm{CD} 8^{+} \mathrm{T}$ cells of asymptomatic but not symptomatic individuals [173]. Thus, inclusion of the tat gene in attenuated or replication-defective HSV1-based vectors is an innovative strategy for development of effective preventive and therapeutic HSV vaccines. Furthermore, administration of Tat to mice acutely infected with Mycobacterium tuberculosis (Mtb) significantly reduced leucocyte infiltration and tissue damage in the lung, suggesting a modulatory role for Tat, also in the early response to Mtb, affecting tuberculosis pathogenesis [174].

\section{Role of the immune response to Tat}

\section{Epidemiological evidence}

Epidemiological studies have shown that asymptomatic patients and non-progressors have a higher prevalence of anti-Tat Abs than progressors [175], as shown by a slower and milder evolution of the disease and a better responsiveness to antiretroviral therapy. In particular, the presence of anti-Tat Abs correlates with a significant containment of $\mathrm{CD}^{+} \mathrm{T}$ cell loss and plasma viral load (VL) increases [175-183]. Regarding cell-mediated immunity, CTLs to Tat are frequently detected in asymptomatic HIV-1-infected individuals and have been shown to inversely correlate with progression to AIDS [184, 185]. Because HIV-infected cells express Tat very early after infection, vaccine-induced anti-Tat CTLs may eliminate infected cells and block HIV infection at an early stage. Furthermore, the detection of anti-Tat CTL escape mutants early after infection in humans highlights the selective pressure that the immune system exerts on Tat and the importance of anti-Tat CTLs early after infection [186, 187]. Thus, the control of HIV replication by CTLs targeted to early proteins, and in particular to Tat, is relevant for the containment of the infection and progression to disease. Indeed, we have very recently reported [188] that, in individuals on long-term ART, antiTat immunity was associated with higher nadir $\mathrm{CD} 4^{+} \mathrm{T}$-cell counts, control of low-level viremia, and long-lasting $\mathrm{CD} 4^{+}$ $\mathrm{T}$ cell recovery, but not with decreased immune activation. In particular, individuals with both humoral responses and a high frequency of cell-mediated responses experienced a progressive increase in $\mathrm{CD} 4^{+} \mathrm{T}$ cells and the $\mathrm{CD} 4^{+} / \mathrm{CD} 8^{+}$ $\mathrm{T}$-cell ratio. These changes were not observed in individuals lacking these responses. Furthermore, the cell-mediated response to Tat, alone or associated with the anti-Tat $\mathrm{Ab}$ response, was also found to be predictive of a significant increase in NK or B cells, respectively. Notably, the anti-Tat antibody level was associated with control of very-low-level viremia, suggesting a block of HIV reactivation from virus reservoirs by Abs targeting extracellular Tat [188].

Altogether, these studies indicate that both the cellular and humoral Tat-specific immune response contribute to the control of infection and/or disease progression.

\section{Preclinical studies with a Tat-based vaccine}

Based on the above epidemiological evidence and its key role in the HIV life cycle and disease pathogenesis, the Tat protein was chosen as a vaccine candidate for preclinical and clinical development for the prevention and treatment of HIV-1 infection. In preclinical studies in nonhuman primates, the Tat protein or tat DNA were found to be safe and to elicit a broad and specific immune response, which protected macaques against challenges with the X4-tropic SHIV89.6P [189-194]. In particular, Tat-specific Ab levels and $\mathrm{CD}^{+}$and $\mathrm{CD}^{+}{ }^{+}$cell responses were high and stable only in the animals that controlled primary infection at its early stages. Of interest, vaccinated and protected macaques did not experience virus rebound upon administration of tetanus toxoid, a stimulus known to activate the immune system and to trigger HIV replication [192]. In addition, vaccinees, but not control animals, were able to contain a second, fivefold higher, intravenous challenge with the same virus upon initial overt infection [193]. Overall, these results indicate that vaccination with Tat had induced long-term memory Tat-specific immune responses, allowing long-term 
containment of virus replication and spread in blood and tissues.

Co-immunization with Tat and other HIV antigens, particularly with Env, underscores the contribution of anti-Tat immunity to vaccine efficacy. In particular, no infection or a statistically significant reduction of viral load and proviral DNA was observed in cynomolgus macaques that had been co-immunized with HIV-1 Tat and Env- $\Delta$ V2 (an oligomeric gp140 protein deleted of the $\mathrm{V} 2$ region) proteins in a complex and challenged intrarectally with a high dose $\left(70 \mathrm{MID}_{50}\right.$ ) of the R5-tropic SHIV SF162P4cy $_{\text {[35]. Rhesus }}$ macaques were immunized mucosally with replicating adenovirus vectors carrying the HIV- 1 clade B tat and env transgenes and then boosted at the systemic level with the Tat and Env proteins. All macaques became infected following intravenous challenge with a high dose of homologous SHIV-89.6P. However, macaques vaccinated with Tat/Env displayed a 4-log lower chronic viremia and experienced a mild $\mathrm{CD}^{+}{ }^{+} \mathrm{T}$ cell loss as compared to control animals [195]. Furthermore, sterilizing immunity or control of infection was observed in rhesus macaques immunized with a multicomponent vaccine (multimeric HIV-1 clade C gp160, HIV-1 clade B Tat, and SIV Gag-Pol particles) delivered either systemically or mucosally and then challenged with the heterologous HIV-C env SHIV-1157ip [196]. The search for humoral correlates of protection identified anti-Tat Abs against the $\mathrm{N}$-terminus of Tat as a relevant one, a finding corroborated by binding and functional assays [197]. Thus, in monkey models of efficacy, both humoral and cellular anti-Tat immunity plays a role in preventing infection and disease progression. Furthermore, Tat/Env co-immunization studies also indicate a role of Tat in modulating the immunogenicity of Env towards potentially protective responses.

\section{Clinical development: preventative and therapeutic phase I trials}

Based on these results, preventative and therapeutic, double blind, placebo-controlled phase I trials with the biologically active Tat (ISS P-001, ClinicalTrials.gov Identifier: NCT00529698; ISS T-001, ClinicalTrials.gov Identifier: NCT00505401) were conducted in Italy, meeting both primary (safety) and secondary (immunogenicity) endpoints [198-200]. The Tat vaccine was safe and, in the HIVinfected volunteers, did not induce virus replication, as indicated by preservation the of $\mathrm{CD} 4^{+} \mathrm{T}$ cell counts and by the absence of significant plasma viremia rebounds. The long-term follow-up (ISS OBS P-001, ClinicalTrials.gov Identifier: NCT01024764) showed the persistence of anti-Tat NAbs up to five years after the first immunization [199, 200].

A phase I preventive trial was also conducted with the combination of Tat and V2-loop-deleted Env ( $\Delta$ V2-Env) in Italy (ISS P-002, ClinicalTrials.gov Identifier:
NCT01441193). This was a multicentric, open-label, phase I trial conducted in healthy volunteers to evaluate the safety and the immunogenicity of the vaccine based on the association of HIV-1 Tat and $\Delta$ V2-Env proteins, as compared to vaccination with single proteins. Tat and $\Delta \mathrm{V} 2$-Env proteins, either in association or as single components, were administered by a prime-boost regimen consisting of three intradermal priming doses followed by two intramuscular boosting injections. The Tat/ $\Delta \mathrm{V} 2$-Env vaccination was safe and immunogenic, as indicated by the development of $\mathrm{Ab}$ responses to the vaccine antigen(s) in all participants [Ensoli, unpublished data]. Importantly, while the highest anti-Tat $\mathrm{Ab}$ response was detected in the subjects vaccinated with Tat alone, the highest anti-Env Ab responses were recorded in the volunteers co-immunized with Tat/ $\Delta \mathrm{V} 2$ Env, which is consistent with previous studies showing better priming provided by Tat-mediated entry of Env in dendritic cells [165].

\section{Clinical development: therapeutic phase II trials}

Moving forward, the therapeutic vaccination was prioritized over the preventive one as a shorter and more cost-effective route to proof of efficacy [201]. Therapeutic phase II trials for cART intensification were conducted in Italy and South Africa in patients on successful cART. The Italian phase II study (ClinicalTrials.gov Identifier: NCT00751595) was an exploratory phase II open-label therapeutic trial, randomized on the different regimens utilized [77, 78]. It enrolled 168 HIV-infected (B clade) anti-Tat Ab-negative adults on longterm (mean $>6$ years) cART who were virologically suppressed, with $\mathrm{CD} 4^{+} \mathrm{T}$ cell counts $\geq 200$ cells $/ \mathrm{mmc}$, and were vaccinated with 7.5 or $30 \mu \mathrm{g}$ of the Tat protein (clade B) without adjuvant, administered intradermally 3 or 5 times, one month apart. Both primary (immunogenicity) and secondary (safety) endpoints were met. No increase in virological biomarkers was observed. The results also showed a reduction in immune activation and durable increases in $\mathrm{CD}^{+}{ }^{+} \mathrm{T}$ cells, $\mathrm{B}$ cells, $\mathrm{NK}$ cells, and $\mathrm{CD} 4^{+}$and $\mathrm{CD} 8^{+}$ central memory $\mathrm{T}$ cell subsets, with a reduction in effector memory cells, indicating a shift of the immune response towards homeostasis [77]. None of these changes were observed in anti-Tat-Ab-negative subjects on effective cART enrolled in a parallel observational study at the same clinical centers (ISS OBS T-002) (ClinicalTrials.gov Identifier: NCT01024556) [77, 78]. Of note, Tat immunization induced a reduction of HIV-1 DNA load in blood, especially in volunteers receiving $30 \mu \mathrm{g}$ of Tat, given three times, that continued throughout the 8-year follow-up (ClinicalTrials.gov Identifier: NCT02118168) [78, 202]. Tat-specific cellular responses also contributed to HIV proviral DNA reduction. Furthermore, the induction, upon vaccination, of $\mathrm{CD} 38^{+} /$

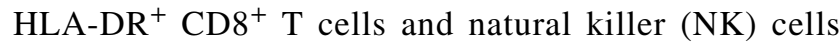


endowed with killer activity against virus-infected cells may have also contributed to the reduction of the virus reservoir. cART intensification by the Tat vaccine was durable, as the increase in $\mathrm{CD}^{+}{ }^{+} \mathrm{T}$ cells persisted during the 8-year followup and was accompanied by a progressive, slow decrease in HIV proviral DNA in the peripheral blood, which became undetectable in $34 \%$ of all vaccinees and in $48 \%$ of volunteers in the group receiving $30 \mu \mathrm{g}$ of Tat three times [202]. These results indicate that the induction of anti-Tat immune responses intensifies cART efficacy and attacks the cART-resistant virus reservoir. A confirmatory randomized, double-blind, placebo-controlled (randomization ratio, 1:1), safety and immunogenicity phase II therapeutic trial (ISS T-003, ClinicalTrials.gov Identifier: NCT01513135) was then conducted in South Africa in 200 HIV-infected (C clade) anti-Tat Ab-negative adults who were virologically suppressed, with $\mathrm{CD} 4^{+} \mathrm{T}$ cell counts $\geq 200$ cells/mmc [203]. The clade-B Tat vaccine $(30 \mu \mathrm{g})$ was administered intradermally three times at monthly intervals. The vaccine was safe and induced durable and high titers of anti-Tat Abs that were capable of cross-recognizing the Tat protein from different HIV clades and cross-neutralizing both clade B and C HIV viruses. Cross-recognition and cross-neutralization correlated with an increase in $\mathrm{CD} 4^{+} \mathrm{T}$ cell counts, a key target for cART intensification [203]. Of note, vaccination contained the $\mathrm{VL}$ rebound and maintained $\mathrm{CD} 4^{+} \mathrm{T}$ cell counts above the baseline levels in subjects who were noncompliant with therapy as compared to (noncompliant) placebo, suggesting that Tat vaccine intensification of cART may counterbalance incomplete adherence to treatment [203]. An extended follow-up study of this trial (ISS T-003 EF-UP) is underway. Overall, the Tat vaccine study shows for the first time that cART can be intensified by therapeutic immunization and that the proviral DNA load can be progressively lowered.

\section{Conclusions}

So far, HIV vaccine design based on structural proteins has not been successful, nor have empirical vaccines, reinforcing the concept that a pathogenetic approach must be undertaken to identify key virulence factors to target with a vaccine. In particular, a "pathogenesis-driven" approach should be aimed at targeting key viral products responsible of virus transmission and activation and maintenance of virus reservoirs. For this, evidence provided by the natural history of infection and lessons from earlier trials are key.

Tat vaccination represents an example of a "pathogenicdriven" intervention that is potentially effective for both preventative and therapeutic strategies, since it is aimed at blocking virus transmission and spread. The rationale is based on the evidence that HIV-1 Tat, which is necessary for HIV gene expression, replication, and cell-to cell transmission, appears also to be critical in the initial steps of virus acquisition. In fact, it has been shown that Tat, which is present on virus particles, binds to Env spikes, promoting HIV infection of dendritic cells and spreading to T lymphocytes, even in the presence of anti-Env NAbs, and that antiTat Abs are necessary to restore neutralization and prevent HIV dissemination, as demonstrated by virus containment at the site of inoculation in macaques vaccinated with Tat and Env- $\Delta \mathrm{V} 2$ proteins and challenged intrarectally with the SHIV $_{\text {SF162P4cy, }}$ but not in control animals [35].

In a therapeutic setting, cART intensification by a Tat vaccine has proven effective at promoting immune system restoration by improving $\mathrm{CD} 4^{+} \mathrm{T}$ cell recovery and immune system functions while reducing virus reservoirs and immune activation/dysregulation [77, 78, 202]. These combined effects may reduce the negative effects of nonadherence to therapy on virus transmission, and hence global community VL, new infections, and drug resistance. Thus, an intervention that restores immune responses may allow periodic drug-free time.

The different therapeutic uses of Tat vaccination in HIV infection must be confirmed in dedicated trials to determine whether administration of Tat in patients receiving longterm (late) cART can provide prolonged post-treatment control (extended drug-free periods with low or undetectable VL) in an analytic treatment interruption (ATI) trial, opening new perspectives for functional cure and eradication strategies. In this regard, the durability of the increase in $\mathrm{CD}^{+} \mathrm{T}$ cell count and the progressive decrease in HIV proviral DNA to undetectable levels observed in vaccinees over the 8-year follow-up [202] are promising, as a reduced proviral HIV-1 DNA load at study entry has been reported to be independently associated with a delayed and milder HIV-1 RNA rebound after ATI [204] and post-treatment control [205].

Moreover, in volunteers who were vaccinated with Tat toxoid and developed a high titer of Abs that neutralized Tat bioactivity, a prolonged off-therapy time was recorded in the 2 years of follow-up [206]. Similarly, a delayed and weaker HIV RNA rebound was observed upon ATI in the volunteers immunized with Tat Oyi, who mounted strong immune responses against Tat [207]. Of note, the 33- $\mu \mathrm{g}$ dose was the most immunogenic and efficacious of the three doses tested $(11,33$, and $99 \mu \mathrm{g})$ [207], which is in substantial agreement with our data from the ISS T-002 trial, in which the 30- $\mu \mathrm{g}$ dose of recombinant Tat protein gave the best results [78].

The Tat vaccine should also be evaluated in poor immunological responders to determine whether it ameliorates the response to cART at the beginning of therapy, with the aim of reducing the time to a virological and immunological response. It is also important to evaluate the Tat vaccine in HIV-infected cART-treated adolescents and children, as they face the longest time on antiretroviral treatment and 
therefore are the ones most needing approaches ensuring virus control despite poor adherence, adoption of therapy simplification regimens, or prolonged time off-therapy. Furthermore, Tat could be used as a co-treatment to improve the efficacy of pre-exposure prophylaxis. It will be very important to evaluate the effects of the Tat vaccine in these contexts on HIV DNA in lymphoid tissues and other compartments, as cART does not attack the latent HIV reservoir, to determine the impact of vaccination on solid-tissue HIV reservoirs and residual disease. If proven effective in phase III efficacy trials, cART intensification by the Tat vaccine will allow the public health system to better target resources towards more-advanced HIV care strategies. In fact, cART intensification by the Tat vaccine is expected to reduce the rate of treatment failure and the prevalence of AIDS and non-AIDS comorbidities and allow periodic drug-free time, particularly in infants, children, and adolescents facing lifelong cART and its severe side-effects, which can lead to low therapy adherence. Moreover, further depletion of the reservoirs of cART-resistant latent HIV resulting from Tat vaccination promises to blunt HIV rebound upon low adherence, which is one of the main causes of the development of drug resistance and virus transmission. Notably, vaccination with Tat in "very early" treatment of acute infection could stall the expansion of HIV reservoirs, opening new perspectives for a functional cure for HIV infection.

The generation of anti-Tat monoclonal Abs (mAbs) for immunotherapy should also be considered, as major advancements have been made in the generation and use of mAbs for immunotherapy [208]. In the few studies that have been conducted so far, mAbs generated in murine models and in humans upon vaccination with the Tat protein and directed against the amino terminus of Tat were effective at blocking Tat-induced transactivation and viral replication [209, 210], even across different Tat clades [211]. Thus, studies thoroughly addressing the protective effects of antiTat mAbs, alone or in association with other therapeutic interventions (cART, broadly neutralizing Abs, latencyreversing agents, etc.) in preclinical models and then in humans, are warranted.

Finally, the inherent Th-1- and CTL-promoting properties of Tat indicate the Tat may represent a new weapon that can be used as a vaccine against HIV/AIDS and as a potent Th-1 regulatory protein for increasing the efficacy of vaccines against other intracellular pathogens, such as HSV and Mtb.

Acknowledgements The authors would like to thank A. Arancio, M. Campagna, V. Francavilla, G. Paniccia, and M.R. Pavone Cossut (National HIV/AIDS Research Center) for laboratory support; F. Cammisa (National HIV/AIDS Research Center) for support to study management and editorial assistance; S. De Menna, F. Fedeli, and S. Tobelli (National HIV/AIDS Research Center) for administrative support; P. Arciero (National HIV/AIDS Research Center) for technical support; and G.B. Cozzone (VAXXIT, Rome, Italy) for helpful discussion

Author contributions Conceptualization, B.E., P.M., S.B., S.M., M.T.M, A.B., and A.C.; methodology, A.C., P.M., S.B., A.T., C.S. and B.E.; data curation, A.T. and O.P.; writing-original draft preparation, S.M., M.T.M, A.B., writing-review and editing, A.C., P.M., S.B., C.S., S.M., M.T.M, A.B., and B.E.; supervision, A.C., P.M., and B.E.; funding acquisition, A.C., P.M. and B.E.

Funding This study was funded by the Italian Ministry of Health, Special Project on the Development of a Vaccine against HIV Based on the Tat protein, the Italian Ministry of Health, grant number F-201102348970 and RF-2016-02364744.

\section{Declarations}

Conflict of interest The authors declare no conflict of interest. The funders had no role in the conceptualization of the study, in the collection, analysis or interpretation of data, in the writing of the manuscript, or in the decision to publish the results.

\section{References}

1. Zhao LP, Fiore-Gartland A, Carpp LN, Cohen KW, Rouphael N, Fleurs L et al (2020) Landscapes of binding antibody and T-cell responses to pox-protein HIV vaccines in Thais and South Africans. PLoS One 15:e0226803. https://doi.org/10.1371/journ al.pone. 0226803

2. Archin NM, Marsh Sung J, Garrido C, Soriano-Sarabia N, Margolis DM (2014) Eradicating HIV-1 infection: seeking to clear a persistent pathogen. Nat Rev Microbiol 12:750-764. https://doi. org/10.1038/nrmicro3352

3. Lassen K, Han Y, Zhou Y, Siliciano J, Siliciano RF (2004) The multifactorial nature of HIV-1 latency. Trends Mol Med 10:525531. https://doi.org/10.1016/j.molmed.2004.09.006

4. Esparza J (2013) A brief history of the global effort to develop a preventive HIV vaccine. Vaccine 31:3502-18. https://doi.org/ 10.1016/j.vaccine.2013.05.018

5. Plotkin SA (2010) Correlates of protection induced by vaccination. Clin Vaccine Immunol 17:1055-65. https://doi.org/10.1128/ CVI.00131-10

6. Araújo LA, Almeida SE (2013) HIV-1 diversity in the envelope glycoproteins: implications for viral entry inhibition. Viruses 5:595-604. https://doi.org/10.3390/v5020595

7. Yates NL, deCamp AC, Korber BT, Liao HX, Irene C, Pinter A, Peacock J, Harris LJ, Sawant S, Hraber P, Shen X, Rerks-Ngarm S, Pitisuttithum P, Nitayapan S, Berman PW, Robb ML, Pantaleo G, Zolla-Pazner S, Haynes BF, Alam SM, Montefiori DC, Tomaras GD (2018) HIV-1 Envelope Glycoproteins from Diverse Clades Differentiate Antibody Responses and Durability among Vaccinees. J Virol 92(8):e01843-17. https://doi.org/10.1128/JVI. 01843-17

8. McMichael AJ, Callan M, Appay V, Hanke T, Ogg G, RowlandJones $S$ (2000) The dynamics of the cellular immune response to HIV infection: implications for vaccination. Philos Trans R Soc Lond B Biol Sci 355:1007-11. https://doi.org/10.1098/rstb. 2000.0637 
9. McMichael A, Hanke T (2002) The quest for an AIDS vaccine: is the CD8+ T-cell approach feasible? Nat Rev Immunol 2:283-91. https://doi.org/10.1038/nri779

10. McMichael AJ, Borrow P, Tomaras GD, Goonetilleke N, Haynes BF (2010) The immune response during acute HIV-1 infection: clues for vaccine development. Nat Rev Immunol 10:11-23. https://doi.org/10.1038/nri2674

11. Mudd PA, Martins MA, Ericsen AJ, Tully DC, Power KA, Bean AT et al (2012) Vaccine-induced CD8+ T cells control AIDS virus replication. Nature 491:129-33. https://doi.org/10.1038/ nature 11443

12. Koup RA, Roederer M, Lamoreaux L, Fischer J, Novik L, Nason MC et al (2010) Priming immunization with DNA augments immunogenicity of recombinant adenoviral vectors for both HIV-1 specific antibody and Tcell responses. PLoS One 5:e9015. https://doi.org/10.1371/journal.pone.0009015

13. Barouch DH (2010) Novel adenovirus vector-based vaccines for HIV-1. Curr Opin HIV AIDS 5:386-90. https://doi.org/10.1097/ COH.0b013e32833cfe4c

14. Wilks AB, Christian EC, Seaman MS, Sircar P, Carville A, Gomez CE, Esteban M, Pantaleo G, Barouch DH, Letvin NL, Permar SR (2010) Robust vaccine-elicited cellular immune responses in breast milk following systemic simian immunodeficiency virus DNA prime and live virus vector boost vaccination of lactating rhesus monkeys. J Immunol 185:7097-106. https:// doi.org/10.4049/jimmunol.1002751

15. Cohen J (2007) AIDS research. Promising AIDS vaccine's failure leaves field reeling. Science 318:28-9. https://doi.org/10.1126/ science.318.5847.28

16. Duerr A, Huang Y, Buchbinder S, Coombs RW, Sanchez J, del Rio $C$ et al (2012) Extended follow-up confirms early vaccineenhanced risk of HIV acquisition and demonstrates waning effect over time among participants in a randomized trial of recombinant adenovirus HIV vaccine (Step Study). J Infect Dis 206:25866. https://doi.org/10.1093/infdis/jis342

17. Buchbinder SP, Mehrotra DV, Duerr A, Fitzgerald DW, Mogg R, Li D et al (2008) Efficacy assessment of a cell-mediated immunity HIV-1 vaccine (the Step Study): a double-blind, randomised, placebo-controlled, test-of-concept trial. Lancet 372:1881-93. https://doi.org/10.1016/S0140-6736(08)61591-3

18. Hammer SM, Sobieszczyk ME, Janes H, Karuna ST, Mulligan MJ, Grove D, Koblin BA, Buchbinder SP, Keefer MC, Tomaras GD, Frahm N, Hural J, Anude C, Graham BS, Enama ME, Adams E, DeJesus E, Novak RM, Frank I, Bentley C, Ramirez S, Fu R, Koup RA, Mascola JR, Nabel GJ, Montefiori DC, Kublin J, McElrath MJ, Corey L, Gilbert PB (2013) N Engl J Med 369:2083-92. https://doi.org/10.1056/NEJMoa1310566

19. Gray GE, Moodie Z, Metch B, Gilbert PB, Bekker LG, Churchyard G, Nchabeleng M, Mlisana K, Laher F, Roux S, Mngadi K, Innes C, Mathebula M, Allen M, McElrath MJ, Robertson M, Kublin J, Corey L, HVTN 503, Phambili study team (2014) Recombinant adenovirus type $5 \mathrm{HIV}$ gag/pol/nef vaccine in South Africa: unblinded, long-term follow-up of the phase $2 b$ HVTN 503/Phambili study. Lancet Infect Dis 14:388-96. https:// doi.org/10.1016/S1473-3099(14)70020-9

20. Gray G, Buchbinder S, Duerr A (2010) Overview of STEP and Phambili trial results: two phase IIb test-of-concept studies investigating the efficacy of MRK adenovirus type $5 \mathrm{gag} / \mathrm{pol} / \mathrm{nef}$ subtype B HIV vaccine. Curr Opin HIV AIDS 5:357-61. https:// doi.org/10.1097/COH.0b013e32833d2d2b

21. Rerks-Ngarm S, Pitisuttithum P, Excler JL, Nitayaphan S, Kaewkungwal J, Premsri N, Kunasol P, Karasavvas N, Schuetz A, Ngauy V, Sinangil F, Dawson P, deCamp AC, Phogat S, Garunathan S, Tartaglia J, DiazGranados C, Ratto-Kim S, Pegu P, Eller M, Karnasuta C, Montefiori DC, Sawant S, Vandergrift N, Wills S, Tomaras GD, Robb ML, Michael NL, Kim JH,
Vasan S, O’Connell RJ, RV305 Study Team (2017) Randomized, Double-Blind Evaluation of Late Boost Strategies for HIV-Uninfected Vaccine Recipients in the RV144 HIV Vaccine Efficacy Trial. J Infect Dis. 215:1255-1263. https://doi.org/10.1093/ infdis/jix09

22. Sun Z, Yan L, Tang J, Qian Q, Lenberg J, Zhu D, Liu W, Wu K, Wang Y, Lu S (2018) Brief introduction of current technologies in isolation of broadly neutralizing HIV-1 antibodies. Virus Res 243:75-82. https://doi.org/10.1016/j.virusres.2017.10.011

23. Kelsoe G, Haynes BF (2017) Host controls of HIV broadly neutralizing antibody development. Immunol Rev 275:79-88. https://doi.org/10.1111/imr.12508

24. Hoot S, McGuire AT, Cohen KW, Strong RK, Hangartner L, Klein F, Diskin R, Scheid JF, Sather DN, Burton DR, Stamatatos L (2013) Recombinant HIV envelope proteins fail to engage germline versions of anti-CD4bs bNAbs. PLoS Pathog 9:e1003106. https://doi.org/10.1371/journal.ppat.1003106

25. McGuire AT, Glenn JA, Lippy A, Stamatatos L (2014) Diverse recombinant HIV-1 Envs fail to activate B cells expressing the germline B cell receptors of the broadly neutralizing anti-HIV-1 antibodies PG9 and 447-52D. J Virol 88:2645-57. https://doi. org/10.1128/JVI.03228-13

26. Bonsignori M, Liao HX, Gao F, Williams WB, Alam SM, Montefiori DC, Haynes BF (2017) Antibody-virus co-evolution in HIV infection: paths for HIV vaccine development. Immunol Rev 275:145-160. https://doi.org/10.1111/imr.12509

27. McGuire AT (2019) Targeting broadly neutralizing antibody precursors: a naïve approach to vaccine design. Curr Opin HIV AIDS 14:294-301. https://doi.org/10.1097/COH.0000000000 000548

28. Burton DR, Hangartner L (2016) Broadly Neutralizing Antibodies to HIV and Their Role in Vaccine Design. Annual Review of Immunology 34:635-659. https://doi.org/10.1146/annurevimmunol-041015-055515

29. Barouch DH, O’Brien KL, Simmons NL, King SL, Abbink P, Maxfield LF, Sun YH, La Porte A, Riggs AM, Lynch DM, Clark SL, Backus K, Perry JR, Seaman MS, Carville A, Mansfield KG, Szinger JJ, Fischer W, Muldoon M, Korber B (2010) Mosaic HIV-1 vaccines expand the breadth and depth of cellular immune responses in rhesus monkeys. Nat Med 16:319-23. https://doi.org/10.1038/nm.2089

30. Lin L, Finak G, Ushey K, Seshadri C, Hawn TR, Frahm N, Scriba TJ, Mahomed H, Hanekom W, Bart PA, Pantaleo G, Tomaras GD, Rerks-Ngarm S, Kaewkungwal J, Nitayaphan S, Pitisuttithum P, Michael NL, Kim JH, Robb ML, O'Connell RJ, Karasavvas N, Gilbert P, De Rosa C, S, McElrath MJ, Gottardo R, (2015) COMPASS identifies T-cell subsets correlated with clinical outcomes. Nat Biotechnol 33:610-6. https://doi.org/10.1038/ nbt. 3187

31. Excler JL, Kim JH (2019) Novel prime-boost vaccine strategies against HIV-1. Expert Rev Vaccin 18:765-779. https://doi.org/ 10.1080/14760584.2019.1640117

32. Chertova E, Chertov O, Coren LV, Roser JD, Trubey CM, Bess JW Jr, Sowder RC 2nd, Barsov E, Hood BL, Fisher RJ et al (2006) Proteomic and biochemical analysis of purified human immunodeficiency virus type 1 produced from infected monocyte-derived macrophages. J Virol 80:9039-9052. https://doi.org/ 10.1128/JVI.01013-06

33. Harrich D, Ulich C, García-Martínez LF, Gaynor RB (1997) Tat is required for efficient HIV-1 reverse transcription. EMBO J 16:1224-1235. https://doi.org/10.1093/emboj/16.6.1224

34. Marchiò S, Alfano M, Primo L, Gramaglia D, Butini L, Gennero L, De Vivo E, Arap W, Giacca M, Pasqualini R et al (2005) Cell surface-associated Tat modulates HIV-1 infection and spreading through a specific interaction with gp120 viral 
envelope protein. Blood 105:2802-2811. https://doi.org/10.1182/ blood-2004-06-2212

35. Monini P, Cafaro A, Srivastava IK, Moretti S, Sharma VA, Andreini C, Chiozzini C, Ferrantelli F, Cossut MR, Tripiciano A et al (2012) HIV-1 tat promotes integrin-mediated HIV transmission to dendritic cells by binding Env spikes and competes neutralization by anti-HIV antibodies. PLoS ONE 7:e48781. https://doi.org/10.1371/journal.pone.0048781

36. Wu Y, Marsh JW (2001) Selective transcription and modulation of resting T cell activity by preintegrated HIV DNA. Science 293:1503-1506. https://doi.org/10.1126/science.1061548

37. Bohan CA, Kashanchi F, Ensoli B, Buonaguro L, Boris-Lawrie KA, Brady JN (1992) Analysis of Tat transactivation of human immunodeficiency virus transcription in vitro. Gene Expr 2:391-407

38. Das AT, Harwig A, Berkhout B (2011) The HIV-1 Tat protein has a versatile role in activating viral transcription. J Virol 85:95069516. https://doi.org/10.1128/JVI.00650-11

39. Feinberg MB, Baltimore D, Frankel AD (1991) The role of Tat in the human immunodeficiency virus life cycle indicates a primary effect on transcriptional elongation. Proc Natl Acad Sci USA 88:4045-4049. https://doi.org/10.1073/pnas.88.9.4045

40. Weinberger LS, Burnett JC, Toettcher JE, Arkin AP, Schaffer DV (2005) Stochastic Gene Expression in a Lentiviral PositiveFeedback Loop. Cell 122:169-182. https://doi.org/10.1016/j.cell. 2005.06.006

41. Razooky BS, Pai A, Aull K, Rouzine IM, Weinberger SL (2015) A Hardwired HIV Latency Program. Cell 160:990-1001. https:// doi.org/10.1016/j.cell.2015.02.009

42. Howcroft TK, Strebel K, Martin MA, Singer DS (1993) Repression of MHC class I gene promoter activity by two-exon Tat of HIV. Science 260:1320-1322. https://doi.org/10.1126/science. 8493575

43. Kanazawa S, Okamoto T, Peterlin BM (2000) Tat competes with CIITA for the binding to P-TEFb and blocks the expression of MHC class II genes in HIV infection. Immunity 12:61-70. https://doi.org/10.1016/S1074-7613(00)80159-4

44. Izmailova E, Bertley FMN, Huang Q et al (2003) HIV-1 Tat reprograms immature dendritic cells to express chemoattractants for activated T cells and macrophages. Nat Med 9:191-197. https://doi.org/10.1038/nm822

45. Ensoli B, Buonaguro L, Barillari G, Fiorelli V, Gendelman R, Morgan RA, Wingfield P, Gallo RC (1993) Release, uptake, and effects of extracellular human immunodeficiency virus type 1 Tat protein on cell growth and viral transactivation. J Virol 67:277-287. https://doi.org/10.1128/JVI.67.1.277-287.1993

46. Chang HC, Samaniego F, Nair BC, Buonaguro L, Ensoli B (1997) HIV-1 Tat protein exits from cells via a leaderless secretory pathway and binds to extracellular matrix-associated heparan sulfate proteoglycans through its basic region. AIDS 11:1421-1431. https://doi.org/10.1097/00002030-199712000-00006

47. Rayne F, Debaisieux S, Yezid H, Lin YL, Mettling C, Konate K, Chazal N, Arold ST, Pugnière M, Sanchez F et al (2010) Phosphatidylinositol-(4,5)-bisphosphate enables efficient secretion of HIV-1 Tat by infected T-cells. EMBO J 29:1348-1362. https://doi.org/10.1038/emboj.2010.32

48. Ensoli B, Barillari G, Salahuddin SZ, Gallo RC, Wong-Staal F (1990) Tat protein of HIV-1 stimulates growth of cells derived from Kaposi's sarcoma lesions of AIDS patients. Nature 345:8486. https://doi.org/10.1038/345084a0

49. Ensoli B, Gendelman R, Markham P, Fiorelli V, Colombini S, Raffeld M, Cafaro A, Chang HK, Brady JN, Gallo RC (1994) Synergy between basic fibroblast growth factor and HIV-1 Tat protein in induction of Kaposi's sarcoma. Nature 371:674-680. https://doi.org/10.1038/371674a0
50. Barillari G, Gendelman R, Gallo RC, Ensoli B (1993) The Tat protein of human immunodeficiency virus type 1, a growth factor for AIDS Kaposi sarcoma and cytokine-activated vascular cells, induces adhesion of the same cell types by using integrin receptors recognizing the RGD amino acid sequence. Proc Natl Acad Sci U S A. https://doi.org/10.1073/pnas.90.17.7941

51. Albini A, Ferrini S, Benelli R, Sforzini S, Giunciuglio D, Aluigi MG, Proudfoot AE, Alouani S, Wells TN, Mariani G et al (1998) HIV-1 Tat protein mimicry of chemokines. Proc Natl Acad Sci USA 95:13153-13158. https://doi.org/10.1073/pnas.95.22.13153

52. Fanales-Belasio E, Moretti S, Nappi F, Barillari G, Micheletti F, Cafaro A, Ensoli B (2002) Native HIV-1 Tat protein targets monocyte-derived dendritic cells and enhances their maturation, function, and antigen-specific $\mathrm{T}$ cell responses. J Immunol 168:197-206. https://doi.org/10.4049/jimmunol.168.1.197

53. Cafaro A, Barillari G, Moretti S, Palladino C, Tripiciano A, Falchi M, Picconi O, Pavone Cossut MR, Campagna M, Arancio A, Sgadari C, Andreini C, Banci L, Monini P, Ensoli B (2020) HIV-1 Tat Protein Enters Dysfunctional Endothelial Cells via Integrins and Renders Them Permissive to Virus Replication. Int J Mol Sci 22:E317. https://doi.org/10.3390/ijms2 2010317

54. Johnson TP, Patel K, Johnson KR, Maric D, Calabresi PA, Hasbun R, Nath A (2013) Induction of IL-17 and nonclassical T-cell activation by HIV-Tat protein. Proc Natl Acad Sci USA 110:13588-13593. https://doi.org/10.1073/pnas.1308673110

55. Huang L, Bosch I, Hofmann W, Sodroski J, Pardee AB (1998) Tat protein induces human immunodeficiency virus type 1 (HIV-1) coreceptors and promotes infection with both macrophage-tropic and T-lymphotropic HIV-1 strains. J. Virol 72:8952-8960. https://doi.org/10.1128/JVI.72.11.8952-8960. 1998

56. Xiao H, Neuveut C, Tiffany HL et al (2000) Selective CXCR4 antagonism by Tat: Implications for in vivo expansion of coreceptor use by HIV-1. Proc Natl Acad Sci USA 97:11466-11471. https://doi.org/10.1073/pnas.97.21.11466

57. Li CJ, Ueda Y, Shi B, Borodyansky L, Huang L, Li YZ, Pardee AB (1997) Tat protein induces self-perpetuating permissivity for productive HIV-1 infection. Proc Natl Acad Sci U S A 94:811620. https://doi.org/10.1073/pnas.94.15.8116

58. Fanales-Belasio E, Moretti S, Fiorelli V, Tripiciano A, Pavone Cossut MR, Scoglio A, Collacchi B, Nappi F, Macchia I, Bellino $\mathrm{S}$ et al (2009) HIV-1 Tat addresses dendritic cells to induce a predominant Th1-type adaptive immune response that appears prevalent in the asymptomatic stage of infection. J Immunol 182:2888-2897. https://doi.org/10.4049/jimmunol.0711406

59. Buonaguro L, Barillari G, Chang HK, Bohan CA, Kao V, Morgan R, Gallo RC, Ensoli B (1992) Effects of the human immunodeficiency virus type 1 Tat protein on the expression of inflammatory cytokines. J Virol 66:7159-7167. https://doi.org/10.1128/JVI.66. 12.7159-7167.1992

60. Scala G, Ruocco MR, Ambrosino C, Mallardo M, Giordano V, Baldassarre F, Dragonetti E, Quinto I, Venuta S (1994) The expression of the interleukin 6 gene is induced by the human immunodeficiency virus 1 TAT protein. J Exp Med 179:961-971. https://doi.org/10.1084/jem.179.3.961

61. Lafrenie RM, Wahl LM, Epstein JS, Yamada KM, Dhawan S (1997) Activation of monocytes by HIV-Tat treatment is mediated by cytokine expression. J Immunol 159:4077-4083

62. Ben Haij N, Planès R, Leghmari K, Serrero M, Delobel P, Izopet J, BenMohamed L, Bahraoui E (2015) HIV-1 Tat Protein Induces Production of Proinflammatory Cytokines by Human Dendritic Cells and Monocytes/Macrophages through Engagement of TLR4-MD2-CD14 Complex and Activation of NF- $\mathrm{KB}$ Pathway. PLoS ONE 10:e0129425. https://doi.org/10.1371/journ al.pone. 0129425 
63. Planès R, Ben Haij N, Leghmari K, Serrero M, BenMohamed L, Bahraoui E (2016) HIV-1 Tat Protein Activates both the MyD88 and TRIF Pathways To Induce Tumor Necrosis Factor Alpha and Interleukin-10 in Human Monocytes. J Virol 90:5886-5898. https://doi.org/10.1128/JVI.00262-16

64. Chiozzini C, Collacchi B, Nappi F, Bauer T, Arenaccio C, Tripiciano A, Longo O, Ensoli F, Cafaro A, Ensoli B et al (2014) Surface-bound Tat inhibits antigen-specific CD8+ T-cell activation in an integrin-dependent manner. AIDS 28:2189-2200. https://doi.org/10.1097/QAD.0000000000000389

65. Jordan A, Bisgrove B, Verdin E (2003) HIV reproducibly establishes latent infection after acute infection of $\mathrm{T}$ cells in vitro. EMBO J 22:1868-77. https://doi.org/10.1093/emboj/ cdg 188

66. Dahabieh MS, Ooms M, Simon V, Sadowski I (2013) A doubly fluorescent hiv-1 reporter shows that the majority of integrated HIV-1 is latent shortly after infection. J Virol 87:4716-4727. https://doi.org/10.1128/JVI.03478-12

67. Chavez L, Calvanese V, Verdin E (2015) HIV latency is established directly and early in both resting and activated CD4 T cells. Plos Pathog 11:e1004955. https://doi.org/10.1371/journal. ppat. 1004955

68. Weinberger AD, Weinberger LS (2013) Stochastic fate selection in HIV-infected patients. Cell 155:499-97. https://doi.org/10. 1016/j.cell.2013.09.039

69. Hosmane NN, Kwon KJ, Bruner KM, Capoferri AA, Beg S, Rosenbloom DI, Keele BF, Ho YC, Siliciano JD, Siliciano RF (2017) Proliferation of latently infected CD4+ T cells carrying replication-competent HIV. J Exp Med 214:959-972. https://doi. org/10.1084/jem.20170193

70. Pinkevych M, Cromer D, Tolstrup M, Grimm AJ, Cooper DA, Lewin SR, Søgaard OS, Rasmussen TA, Kent SJ, Kelleher AD (2015) Davenport MP (2015) HIV Reactivation from Latency after Treatment Interruption Occurs on Average Every 5-8 Days Implications for HIV Remission. PLoS Pathog 11:e1005000. https://doi.org/10.1371/journal.ppat.1005745

71. Zerbato JM, Purves HV, Lewin SR, Rasmussen TA (2019) Between a shock and a hard place: challenges and developments in HIV latency reversal. Curr Opin Virol 38:1-9. https://doi.org/ 10.1016/j.coviro.2019.03.004

72. Moranguinho I, Valente ST (2020) Block-And-Lock: New Horizons for a Cure for HIV-1. Viruses 12:1443. https://doi.org/10. 3390/v12121443

73. Sengupta S, Siliciano RF (2018) Targeting the Latent Reservoir for HIV-1. Immunity 48:872-95. https://doi.org/10.1016/j. immuni.2018.04.030

74. Aamer HA, McClure J, Ko D et al (2020) Cells producing residual viremia during antiretroviral treatment appear to contribute to rebound viremia following interruption of treatment. Plos Pathog 16:e1008791. https://doi.org/10.1371/journal.ppat.1008791

75. Nicoli F, Gallerani E, Sforza F, Finessi V, Chachage M, Geldmacher C, Cafaro A, Ensoli B, Caputo A, Gavioli R (2018) The HIV-1 Tat protein affects human CD4+ T-cell programming and activation, and favors the differentiation of naïve CD4+ T cells. AIDS 32:575-581. https://doi.org/10.1097/QAD.0000000000 001734

76. Lin X, Irwin D, Kanazawa S, Huang L, Romeo J, Yen TS, Peterlin BM (2003) Transcriptional profiles of latent human immunodeficiency virus in infected individuals: Effects of Tat on the host and reservoir. J Virol 77:8227-8236. https://doi.org/10.1128/JVI. 77.15.8227-8236.2003

77. Ensoli B, Bellino S, Tripiciano A, Longo O, Francavilla V, Marcotullio S, Cafaro A, Picconi O, Paniccia G, Scoglio A et al (2010) Therapeutic immunization with HIV-1 Tat reduces immune activation and loss of regulatory T-cells and improves immune function in subjects on HAART. PLoS ONE 5:e13540. https://doi.org/10.1371/journal.pone.0013540

78. Ensoli F, Cafaro A, Casabianca A, Tripiciano A, Bellino S, Longo O, Francavilla V, Picconi O, Sgadari C, Moretti S et al (2015) HIV-1 Tat immunization restores immune homeostasis and attacks the HAART-resistant blood HIV DNA: Results of a randomized phase II exploratory clinical trial. Retrovirology 12:33. https://doi.org/10.1186/s12977-015-0151-y

79. Kieffer TL, Finucane MM, Nettles RE et al (2004) Genotypic analysis of HIV-1 drug resistance at the limit of detection: virus production without evolution in treated adults with undetectable HIV loads. J Infect Dis 189:1452-65. https://doi.org/10.1086/ 382488

80. Kearney MF, Spindler J, Shao W et al (2014) Lack of detectable hiv-1 molecular evolution during suppressive antiretroviral therapy. PLoS Pathog 10:e1004010. https://doi.org/10.1371/journal. ppat. 1004010

81. Brodin J, Zanini F, Thebo L, et al. (2016) Establishment and stability of the latent HIV-1 DNA reservoir. eLife 5: e18889. https://doi.org/10.7554/eLife.18889

82. Van Zyl GU, Katusiime MG, Wiegand A et al (2017) No evidence of HIV replication in children on antiretroviral therapy. J Clin Invest 127:3827-3834. https://doi.org/10.1172/JCI94582

83. McManus WR, Bale MJ, Spindler J et al (2019) HIV-1 in lymph nodes is maintained by cellular proliferation during antiretroviral therapy. J Clin Invest 129:4629-4642. https://doi.org/10.1172/ JCI126714

84. Abrahams MR, Joseph SB, Garrett N et al (2019) The replication-competent HIV-1 latent reservoir is primarily established near the time of therapy initiation. Sci Transl Med. https://doi. org/10.1126/scitranslmed.aaw5589

85. Tobin NH, Learn GH, Holte SE, at al. (2005) Evidence that lowlevel viremias during effective highly active antiretroviral therapy result from two processes: expression of archival virus and replication of virus. J Virol 79:9625-9634. https://doi.org/10.1128/ JVI.79.15.9625-9634.2005

86. Buzón MJ, Massanella M, Llibre JM et al (2010) HIV-1 replication and immune dynamics are affected by raltegravir intensification of HAART-suppressed subjects. Nat Med 16:460-65. https://doi.org/10.1038/nm.2111

87. Hatano H, Strain MC, Scherzer R (2013) Increase in 2-Long Terminal Repeat Circles and Decrease in D-dimer After Raltegravir Intensification in Patients With Treated HIV Infection: A Randomized, Placebo-Controlled Trial. J Infect Dis 208:1436-42. https://doi.org/10.1093/infdis/jit453

88. Fletcher CV, Staskus K, Wietgrefe SV et al (2014) Persistent HIV-1 replication in low drug concentration lymphatic tissues. Proc Natl Acad Sci USA 111:2307-2312. https://doi.org/10. 1073/pnas.1318249111

89. Lorenzo-Redondo R, Fryer HR, Bedford T, Kim EY, Archer J, Pond SLK, Chung YS, Penugonda S, Chipman J, Fletcher CV, Schacker TW, Malim MH, Rambaut A, Haase AT, McLean AR, Wolinsky SM (2016) Persistent HIV-1 replication maintains the tissue reservoir during therapy. Nature 530:51-56. https://doi. org/10.1038/nature 16933

90. Shan L, Deng K, Gao H et al (2017) Transcriptional reprogramming during effector-to-memory transition renders CD4+ T cells permissive for latent HIV-1 infection. Immunity 47:766-775. https://doi.org/10.1016/j.immuni.2017.09.014

91. López-Huertas MR, Mateos E, Sánchez Del Cojo M, GómezEsquer F, Díaz-Gil G, Rodríguez-Mora S, López JA, Calvo E, López-Campos G, Alcamí J et al (2013) The presence of HIV-1 Tat protein second exon delays fas protein-mediated apoptosis in CD4+ T lymphocytes: A potential mechanism for persistent viral production. J Biol Chem 288:7626-7644. https://doi.org/ 10.1074/jbc.M112.408294 
92. Sgadari C, Barillari G, Palladino C, Bellino S, Taddeo B, Toschi E, Ensoli B (2011) Fibroblast Growth Factor-2 and the HIV-1 Tat Protein Synergize in Promoting Bcl-2 Expression and Preventing Endothelial Cell Apoptosis: Implications for the Pathogenesis of AIDS-Associated Kaposi's Sarcoma. Int J Vasc Med. https://doi. org/10.1155/2011/452729

93. Zauli G, Gibellini D, Caputo A, Bassini A, Negrini M, Monne M, Mazzoni M, Capitani S (1995) The human immunodeficiency virus type-1 Tat protein upregulates Bcl-2 gene expression in Jurkat T-cell lines and primary peripheral blood mononuclear cells. Blood 86:3823-3834

94. Ren Y, Huang SH, Patel S, Alberto WDC, Magat D, Ahimovic D, Macedo AB, Durga R, Chan D, Zale E, Mota TM, Truong R, Rohwetter T, McCann CD, Kovacs CM, Benko E, Wimpelberg A, Cannon C, Hardy WD, Bosque A, Bollard CM, Jones RB (2020) BCL-2 antagonism sensitizes cytotoxic T cell-resistant HIV reservoirs to elimination ex vivo. J Clin Invest 130:25422559. https://doi.org/10.1172/JCI13237

95. Zicari S, Sessa L, Cotugno N, Ruggiero A, Morrocchi E, Concato C, Rocca S, Zangari P, Manno EC, Palma P (2019) Immune Activation, Inflammation, and Non-AIDS Co-Morbidities in HIV-Infected Patients under Long-Term ART. Viruses. https:// doi.org/10.3390/v11030200

96. Deeks SG, Lewin SR, Havlir DV (2013) The end of AIDS: HIV infection as a chronic disease. Lancet 382:1525-33. https://doi. org/10.1016/S0140-6736(13)61809-7

97. Mediouni S, Darque A, Baillat G, Ravaux I, Dhiver C, TissotDupont H, Mokhtari M, Moreau H, Tamalet C, Brunet C, Paul P, Dignat-George F, Stein A, Brouqui P, Spector SA, Campbell GR, Loret EP (2012) Antiretroviral therapy does not block the secretion of the human immunodeficiency virus tat protein. Infect Disord Drug Targets 12:81-86. https://doi.org/10.2174/18715 2612798994939

98. Ferdin J, Goričar K, Dolžan V, Plemenitaš A, Martin JN, Peterlin BM, Deeks SG, Lenassi M (2018) Viral protein Nef is detected in plasma of half of HIV-infected adults with undetectable plasma HIV RNA. PLoS ONE 13:e0191613. https://doi.org/10.1371/ journal.pone. 0191613

99. Sigal A, Kim JT, Balazs AB, Dekel E, Mayo A, Milo R, Baltimore D (2011) Cell-to-cell spread of HIV permits ongoing replication despite antiretroviral therapy. Nature 477:95-8. https:// doi.org/10.1038/nature10347

100. Cobucci RNO, Lima PH, Carvalho de Souza P, Costa VV et al (2015) Assessing the impact of HAART on the incidence of defining and non-defining AIDS cancers among patients with HIV/AIDS: a systematic review. J Infect Public Health 8:1-10. https://doi.org/10.1016/j.jiph.2014.08.003

101. Barillari G, Sgadari C, Fiorelli V, Samaniego F, Colombini S, Manzari V, Modesti A, Nair BC, Cafaro A, Stürzl M, Ensoli B (1999) The Tat protein of human immunodeficiency virus type-1 promotes vascular cell growth and locomotion by engaging the alpha5beta1 and alphavbeta3 integrins and by mobilizing sequestered basic fibroblast growth factor. Blood 94:663-672

102. Barillari G, Sgadari C, Palladino C, Gendelman R, Caputo A, Morris CB, Nair BC, Markham P, Nel A, Stürzl M, Ensoli B (1999) Inflammatory cytokines synergize with the HIV-1 Tat protein to promote angiogenesis and Kaposi's sarcoma via induction of basic fibroblast growth factor and the alpha $\mathrm{v}$ beta 3 integrin. J Immunol 163:1929-1935

103. Barillari G, Ensoli B (2002) Angiogenic effects of extracellular human immunodeficiency virus type 1 Tat protein and its role in the pathogenesis of AIDS-associated Kaposi's sarcoma. Clin Microbiol Rev 15:310-26. https://doi.org/10.1128/cmr.15.2.310326.2002
104. Fiorelli V, Gendelman R, Samaniego F, Markham PD, Ensoli B (1995) Cytokines from activated $\mathrm{T}$ cells induce normal endothelial cells to acquire the phenotypic and functional features of AIDS-Kaposi's sarcoma spindle cells. J Clin Invest 1995(95):1723-34. https://doi.org/10.1172/JCI117849

105. Fiorelli V, Gendelman R, Sirianni MC, Chang HK, Colombini S, Markham PD, Monini P, Sonnabend J, Pintus A, Gallo RC, Ensoli B (1998) gamma-Interferon produced by CD8+ T cells infiltrating Kaposi's sarcoma induces spindle cells with angiogenic phenotype and synergy with human immunodeficiency virus-1 Tat protein: an immune response to human herpesvirus- 8 infection? Blood 91:956-967

106. Fiorelli V, Barillari G, Toschi E, Sgadari C, Monini P, Stürzl M, Ensoli B (1999) IFN-gamma induces endothelial cells to proliferate and to invade the extracellular matrix in response to the HIV-1 Tat protein: implications for AIDS-Kaposi's sarcoma pathogenesis. J Immunol 162:1165-1170

107. Yang WS, Lin TY, Chang L, Yeh WW, Huang SC, Chen TY, Hsieh YT, Chen ST, Li WC, Pan CC, Campbell M, Yen CH, Chen YA, Chang PC (2020) HIV-1 Tat interacts with a Kaposi's sarcoma-associated Herpesvirus reactivation-upregulated antiangiogenic long noncoding RNA, LINC00313, and antagonizes its function. J Virol 94:e01280-19. https://doi.org/10.1128/JVI. 01280-19

108. Dandachi D, Morón F (2020) Effects of HIV on the tumor microenvironment. Adv Exp Med Biol 1263:45-54. https://doi.org/10. 1007/978-3-030-44518-8_4

109. Zeng Y, Zhang X, Huang Z, Cheng L, Yao S, Qin D, Chen X, Tang Q, Lv Z, Zhang L, Lu C (2007) Intracellular Tat of human immunodeficiency virus type 1 activates lytic cycle replication of Kaposi's sarcoma-associated herpesvirus: role of JAK/STAT signaling. J Virol 81:2401-17. https://doi.org/10.1128/JVI. 02024-06

110. Zhou F, Xue M, Qin D, Zhu X, Wang C, Zhu J, Hao T, Cheng L, Chen X, Bai Z, Feng N, Gao SJ, Chun LuC (2013) HIV-1 Tat promotes Kaposi's sarcoma-associated herpesvirus (KSHV) vIL6 -induced angiogenesis and tumorigenesis by regulating PI3K/ PTEN/AKT/GSK-3 $\beta$ signaling pathway. PLoS One 8:e53145. https://doi.org/10.1371/journal.pone.0053145

111. Longworth MS, Laimins LA (2004) Pathogenesis of human papillomaviruses in differentiating epithelia. Microbiol Mol Biol Rev 68:362-72. https://doi.org/10.1128/MMBR.68.2.362-372.2004

112. Tornesello ML, Buonaguro FM, Beth-Giraldo E, Giraldo G (1993) Human immunodeficiency virus type 1 tat gene enhances human papillomavirus early gene expression. Intervirology 36:57-64. https://doi.org/10.1159/000150322

113. Nyagol J, Leucci E, Onnis A, De Falco G, Tigli C, Sanseverino F, Torriccelli M, Palummo N, Pacenti L, Santopietro R, Spina D, Gichangi P, Muchiri L, Lazzi S, Petraglia F, Leoncini L, Giordano A (2006) The effects of HIV-1 Tat protein on cell cycle during cervical carcinogenesis. Cancer Biol Ther 5:684-90. https://doi.org/10.4161/cbt.5.6.2907

114. Tugizov SM, Herrera R, Chin-Hong P, Veluppillai P, Greenspan D, Berry JM, Pilcher CD, Shiboski CH, Jay N, Rubin M, Chein A, Joel M (2013) HIV-associated disruption of mucosal epithelium facilitates paracellular penetration by human papillomavirus. Virology 446:378-88. https://doi.org/10.1016/j.virol.2013. 08.018

115. Brickman C, Palefsky JM (2015) Human papillomavirus in the HIV-infected host: epidemiology and pathogenesis in the antiretroviral era. Curr HIV/AIDS Rep 12:6-15. https://doi.org/ 10.1007/s11904-014-0254-4

116. Barillari G, Palladino C, Bacigalupo I, Leone P, Falchi M, Ensoli B (2016) Entrance of the Tat protein of HIV-1 into human uterine cervical carcinoma cells causes upregulation of HPV-E6 
expression and a decrease in p53 protein levels. Oncol Lett 12:2389-2394. https://doi.org/10.3892/ol.2016.4921

117. Colombrino E, Rossi E, Ballon G, Terrin L, Indraccolo S, Chieco-Bianchi L, De Rossi A (2004) Human immunodeficiency virus type 1 Tat protein modulates cell cycle and apoptosis in Epstein-Barr virus-immortalized B cells. Exp Cell Res 295:53948. https://doi.org/10.1016/j.yexcr.2004.01.018

118. Germini D, Tsfasman T, Klibi M, El-Amine R, Pichugin A, Iarovaia OV, Bilhou-Nabera C, Subra F, Bou Saada Y, Sukhanova A, Boutboul D, Raphaël M, Wiels J, Razin SV, Bury-Moné S, Oksenhendler E, Lipinski M, Vassetzky YS (2017) HIV Tat induces a prolonged MYC relocalization next to IGH in circulating B-cells. Leukemia 31:2515-2522. https://doi.org/10.1038/ leu.2017.106

119. Carbone A, Volpi CC, Gualeni AV, Gloghini A (2017) EpsteinBarr virus associated lymphomas in people with HIV. Curr Opin HIV AIDS 12:39-46. https://doi.org/10.1097/COH.0000000000 000333

120. El-Amine R, Germini D, Zakharova VV, Tsfasman T, Sheval EV, Louzada RAN, Dupuy C, Bilhou-Nabera C, Hamade A, Najjar F, Oksenhendler E, Lipinski M, Chernyak BV, Vassetzky YS (2018) HIV-1 Tat protein induces DNA damage in human peripheral blood B-lymphocytes via mitochondrial ROS production. Redox Biol 15:97-108. https://doi.org/10.1016/j.redox.2017.11.024

121. Wang X, Duan Z, Yu G, Fan M, Scharff MD (2018) Human immunodeficiency virus Tat protein aids $\mathrm{V}$ region somatic hypermutation in human B cells. mBio 9:e02315-17. https://doi.org/ 10.1128/mBio.02315-17

122. Sall FB, El Amine R, Markozashvili D, Tsfasman T, Oksenhendler E, Lipinski M, Vassetzky Y, Germini D (2019) HIV-1 Tat protein induces aberrant activation of AICDA in human B-lymphocytes from peripheral blood. J Cell Physiol. https:// doi.org/10.1002/jcp.28219

123. Duan M, Yao H, Hu G, Chen X, Lund AK, Buch S (2013) HIV Tat induces expression of ICAM-1 in HUVECs: implications for miR-221/-222 in HIV-associated cardiomyopathy. PLoS One 8:e60170. https://doi.org/10.1371/journal.pone.0060170

124. Wang T, Yi R, Green LA, Chelvanambi S, Seimetz M, Clauss M (2015) Increased cardiovascular disease risk in the HIV-positive population on ART: potential role of HIV-Nef and Tat. Cardiovasc Pathol 24:279-82. https://doi.org/10.1016/j.carpath.2015. 07.001

125. Jiang Y, Chai L, Blessing Fasae M, Bai Y (2018) The role of HIV Tat protein in HIV-related cardiovascular diseases. J Transl Med 16:121. https://doi.org/10.1186/s12967-018-1500-0

126. Ajasin D, Eugenin EA (2020) HIV-1 Tat: Role in Bystander Toxicity. Front Cell Infect Microbiol 10:61. https://doi.org/10.3389/ fcimb.2020.00061

127. Doublier S, Zennaro C, Spatola T, Lupia E, Bottelli A, Deregibus MC, Carraro M, Conaldi PG, Camussi G (2007) HIV-1 Tat reduces nephrin in human podocytes: a potential mechanism for enhanced glomerular permeability in HIV-associated nephropathy. AIDS 21:423-32. https://doi.org/10.1097/QAD.0b013e3280 $12 \mathrm{c} 522$

128. Tang P, Das JR, Li J, Yu J, Ray PE (2020) An HIV-Tat inducible mouse model system of childhood HIV-associated nephropathy. Dis Model Mech 13:dmm045641. https://doi.org/10.1242/dmm. 045641

129. Gibellini D, De Crignis E, Ponti C, Borderi M, Clò A, Miserocchi A, Viale P, Re MC (2010) HIV-1 Tat protein enhances RANKL/M-CSF-mediated osteoclast differentiation. Biochem Biophys Res Commun 401:429-34. https://doi.org/10.1016/j. bbrc.2010.09.071

130. Chew N, Tan E, Li L, Lim R (2014) HIV-1 tat and rev upregulates osteoclast bone resorption. J Int AIDS Soc 17:19724. https://doi.org/10.7448/IAS.17.4.19724
131. Beaupere C, Garcia M, Larghero J, Fève B, Capeau J, Lagathu C (2015) The HIV proteins Tat and Nef promote human bone marrow mesenchymal stem cell senescence and alter osteoblastic differentiation. Aging Cell 14:534-46. https://doi.org/10.1111/ acel. 12308

132. Berni Canani R, Cirillo P, Mallardo G, Buccigrossi V, Secondo A, Annunziato L, Bruzzese E, Albano F, Selvaggi F, Guarino A (2003) Effects of HIV-1 Tat protein on ion secretion and on cell proliferation in human intestinal epithelial cells. Gastroenterology 124:368-76. https://doi.org/10.1053/gast.2003.50056

133. Esposito G, Capoccia E, Gigli S, Pesce M, Bruzzese E, D’Alessandro A, Cirillo C, di Cerbo A, Cuomo R, Seguella L, Steardo L, Sarnelli G (2017) HIV-1 Tat-induced diarrhea evokes an enteric glia-dependent neuroinflammatory response in the central nervous system. Sci Rep 10(7):7735. https://doi.org/10. 1038/s41598-017-05245-9

134. Sarnelli G, Seguella L, Pesce M, Lu J, Gigli S, Bruzzese E, Lattanzi R, D’Alessandro A, Cuomo R, Steardo L, Esposito G (2018) HIV-1 Tat-induced diarrhea is improved by the PPARalpha agonist, palmitoylethanolamide, by suppressing the activation of enteric glia. J Neuroinflammation 15:94. https://doi.org/ 10.1186/s12974-018-1126-4

135. Mermis J, Gu H, Xue B, Li F, Tawfik O, Buch S, Bartolome S, O'Brien-Ladner A, Dhillon NK (2011) Hypoxia-inducible factor-1/platelet derived growth factor axis in HIV-associated pulmonary vascular remodeling. Respir Res 12:103. https://doi. org/10.1186/1465-9921-12-103

136. Chinnapaiyan S, Dutta R, Bala J, Parira T, Agudelo M, Nair M, Unwalla HJ (2018) Cigarette smoke promotes HIV infection of primary bronchial epithelium and additively suppresses CFTR function. Sci Rep 8:7984. https://doi.org/10.1038/ s41598-018-26095-Z

137. Cribbs SK, Crothers K, Morris A (2020) Pathogenesis of HIVrelated lung disease: immunity, infection, and inflammation. Physiol Rev 100:603-632. https://doi.org/10.1152/physrev. 00039.2018

138. Liu X, Jana M, Dasgupta S, Koka S, He J, Wood C, Pahan K (2002) Human immunodeficiency virus type-1 (HIV-1) Tat induces nitric oxide synthase in human astroglia. J Biol Chem 277:3912-39319. https://doi.org/10.1074/jbc.M205107200

139. Kim TA, Avraham HK, Koh YH, Jiang S, Park IW, Avraham S (2003) HIV-1 Tat-mediated apoptosis in human brain microvascular endothelial cells. J Immunol 170:2629-2637. https://doi. org/10.4049/jimmunol.170.5.2629

140. Langford D, Oh Kim B, Zou W, Fan Y, Rahimain P, Liu Y, He JJ (2018) Doxycycline-inducible and astrocyte-specific HIV-1 Tat transgenic mice (iTat) as an HIV/neuroAIDS model. J Neurovirol 24:168-179. https://doi.org/10.1007/s13365-017-0598-9

141. Marino J, Maubert ME, Mele AR, Spector C, Wigdahl B, Nonnemacher MR (2020) Functional impact of HIV-1 Tat on cells of the CNS and its role in HAND. Cell Mol Life Sci 77:5079-5099. https://doi.org/10.1007/s00018-020-03561-4

142. Nicoli F, Finessi V, Sicurella M, Rizzotto L, Gallerani E, Destro F, Cafaro A, Marconi P, Caputo A, Ensoli B, Gavioli R (2013) The HIV-1 Tat protein induces the activation of CD8(+)T cells and affects in vivo the magnitude and kinetics of antiviral responses. PLoS One 8:e77746. https://doi.org/10.1371/journal. pone. 0077746

143. Comandini A, Naro C, Adamo R, Akbar AN, Lanna A, Bonmassar E, Franzese O (2013) Molecular mechanisms involved in HIV-1-Tat mediated inhibition of telomerase activity in human CD4(+) T lymphocytes. Mol Immunol 54:181-92. https://doi. org/10.1016/j.molimm.2012.12.003

144. Sforza F, Nicoli F, Gallerani E, Finessi V, Reali E, Cafaro A, Caputo A, Ensoli B, Gavioli R (2014) HIV-1 Tat affects the programming and functionality of human $\mathrm{CD} 8(+) \mathrm{T}$ cells by 
modulating the expression of T-box transcription factors. AIDS 28:1729-1738. https://doi.org/10.1097/QAD.0000000000 000315

145. White MK, Gorrill TS, Kamel Khalili K (2006) Reciprocal transactivation between HIV-1 and other human viruses. Virology 352:1-13. https://doi.org/10.1016/j.virol.2006.04.006

146. Ensoli B, Lusso P, Schachter F, Josephs SF, Rappaport J, Negro F, Gallo RC, Wong-Staal F (1989) Human herpes virus-6 increases HIV-1 expression in co-infected T cells via nuclear factors binding to the HIV-1 enhancer. EMBO J 8(10):3019-3027

147. Wortman MJ, Krachmarov CP, Kim JH, Gordon RG, Chepenik LG, Brady JN, Gallia GL, Khalili K, Johnson EM (2000) Interaction of HIV-1 Tat with Puralpha in nuclei of human glial cells: characterization of RNA-mediated protein-protein binding. $\mathrm{J}$ Cell Biochem 77:65-74. https://doi.org/10.1002/(sici)10974644(20000401)77:1<65::aid-jcb7>3.0.co;2-u

148. Mischitelli M, Fioriti D, Videtta M, Degener AM, Antinori A, Cinque P, Giordano A, Pietropaolo V (2005) Investigation on the role of cell transcriptional factor Sp1 and HIV-1 TAT protein in PML onset or development. J Cell Physiol 204:913-8. https:// doi.org/10.1002/jcp.20375

149. Schafer SL, Vlach J, Pitha PM (1996) Cooperation between herpes simplex virus type 1-encoded ICP0 and Tat to support transcription of human immunodeficiency virus type 1 long terminal repeat in vivo can occur in the absence of the TAR binding site. J Virol 70:6937-6946. https://doi.org/10.1128/JVI.70.10.69376946.1996

150. Karalic D, Lazarevic I, Banko A, Cupic M, Jevtovic D, Jovanovic T (2016) Molecular characterization of BK virus in patients infected with human immunodeficiency virus. Med Microbiol Immunol 205:185-93. https://doi.org/10.1007/ s00430-015-0439-5

151. Munawwar A, Singh S (2016) Human Herpesviruses as Copathogens of HIV Infection, Their Role in HIV Transmission, and Disease Progression. J Lab Physicians 8:5-18. https://doi.org/ 10.4103/0974-2727.176228

152. Crowle AJ, Ross ER, Cohn DL, Gilden J, May MH (1992) Comparison of the abilities of Mycobacterium avium and Mycobacterium intracellulare to infect and multiply in cultured human macrophages from normal and human immunodeficiency virusinfected subjects. Infect Immun 60:3697-3703. https://doi.org/ 10.1128/IAI.60.9.3697-3703.1992

153. Denis M (1994) Tat protein from HIV-1 binds to Mycobacterium avium via a bacterial integrin. Effects on extracellular and intracellular growth. J Immunol 153:2072-2081

154. Kitaura H, Ohara N, Kobayashi K, Yamada T (2001) TNF-alphamediated activation of HIV-1 LTR in monocytoid cells by mycobacteria. FEMS Immunol Med Microbiol 31:97-103. https://doi. org/10.1111/j.1574-695X.2001.tb00505.x

155. Toossi Z, Wu M, Islam N, Teixeira-Johnson L, Hejal R, Aung $\mathrm{H}$ (2004) Transactivation of human immunodeficiency virus-1 in T-cells by Mycobacterium tuberculosis-infected mononuclear phagocytes. J Lab Clin Med 144:108-115. https://doi.org/10. 1016/j.lab.2004.05.012

156. Gruber A, Lell CP, Speth C, Stoiber H, Lass-Florl C, Sonneborn A, Ernst JF, Dierich MP, Würzner R (2001) Human immunodeficiency virus type 1 Tat binds to Candida albicans, inducing hyphae but augmenting phagocytosis in vitro. Immunology 104:455-461. https://doi.org/10.1046/j.1365-2567.2001.01328.x

157. Li JC, Yim HC, Lau ASY (2010) Role of HIV-1 Tat in AIDS pathogenesis: its effects on cytokine dysregulation and contributions to the pathogenesis of opportunistic infection. AIDS 24:1609-23. https://doi.org/10.1097/QAD.0b013e32833ac6a0

158. Wei J, Zhang Y, Knapp PE, Zhao T (2016) HIV-1 Tat regulates the expression of the dcw operon and stimulates the proliferation of bacteria. Microb Pathog 90:34-40. https://doi.org/10.1016/j. micpath.2015.11.005

159. de Carvalho Vivarini A, de Meirelles Santos Pereira R, Barretode-Souza V, Temerozo JR, Soares DC, Saraiva EM, Mattos Saliba A, Chequer Bou-Habib D, Gazos Lopes U (2015) HIV-1 Tat protein enhances the intracellular growth of Leishmania amazonensis via the ds-RNA induced protein PKR. Sci Rep 26:16777. https://doi.org/10.1038/srep16777

160. O'Hara SP, Small AJ, Gajdos GB, Badley AD, Chen XM, Larusso NF (2009) HIV-1 Tat protein suppresses cholangiocyte toll-like receptor 4 expression and defense against Cryptosporidium parvum. J Infect Dis 199:1195-1204. https://doi.org/ $10.1086 / 597387$

161. Ensoli B, Cafaro A, Caputo A, Fiorelli V, Ensoli F, Gavioli R, Ferrantelli F, Cara A, Titti F, Magnani M (2005) Vaccines based on the native HIV Tat protein and on the combination of Tat and the structural HIV protein variant DeltaV2 Env. Microbes Infect 7:1392-9. https://doi.org/10.1016/j.micinf.2005.07.016

162. Hel Z, Tsai WP, Tryniszewska E, Nacsa J, Markham PD, Lewis MG, Pavlakis GN, Felber BK, Tartaglia J, Franchini G (2006) Improved vaccine protection from simian AIDS by the addition of nonstructural simian immunodeficiency virus genes. J Immunol 176:85-96. https://doi.org/10.4049/jimmunol.176.1.85

163. Mooij P, Nieuwenhuis IG, Knoop CJ, Doms RW, Bogers W, Ten Haaft P, Niphuis H, Koornstra W, Bieler K, Köstler J, Morein B, Cafaro A, Ensoli B, Wagner R, Heeney JL (2004) Qualitative T-helper responses to multiple viral antigens correlate with vaccine-induced immunity to simian/human immunodeficiency virus infection. J Virol 78:3333-42. https://doi.org/10.1128/jvi. 78.7.3333-3342.2004

164. Zhao J, Voltan R, Peng B, Davis-Warren A, Kalyanaraman VS, Alvord W (2005) Enhanced cellular immunity to SIV Gag following co-administration of adenoviruses encoding wild-type or mutant HIV Tat and SIV Gag. Virology 342:1-12. https://doi. org/10.1016/j.virol.2005.07.016

165. Gavioli R, Cellini S, Castaldello A, Voltan R, Gallerani E, Gagliardoni F, Fortini C, Cofano EB, Triulzi C, Cafaro A et al (2008) The Tat protein broadens $\mathrm{T}$ cell responses directed to the HIV-1 antigens Gag and Env: Implications for the design of new vaccination strategies against AIDS. Vaccine 26:727-737. https:// doi.org/10.1016/j.vaccine.2007.11.040

166. Gavioli R, Gallerani E, Fortini C, Fabris M, Bottoni A, Canella A, Bonaccorsi A, Marastoni M, Micheletti F, Cafaro A et al (2004) HIV-1 tat protein modulates the generation of cytotoxic $\mathrm{T}$ cell epitopes by modifying proteasome composition and enzymatic activity. J Immunol 173:3838-3843. https://doi.org/10. 4049/jimmunol.173.6.3838

167. Leifert JA, Holler PD, Harkins S, Kranz DM, Whitton JL (2003) The cationic region from HIV tat enhances the cell-surface expression of epitope/MHC class I complexes. Gene Ther 10:2067-73. https://doi.org/10.1038/sj.gt.3302115

168. Kittiworakarn J, Lecoq A, Moine G, Thai R, Lajeunesse E, Drevet P, Vidaud C, Ménez A, Léonetti M (2006) HIV-1 Tat raises an adjuvant-free humoral immune response controlled by its core region and its ability to form cysteine-mediated oligomers. J Biol Chem 281:3105-15. https://doi.org/10.1074/jbc. M509899200

169. Sicurella M, Nicoli F, Gallerani E, Volpi I, Berto E, Finessi V, Destro F, Manservigi R, Cafaro A, Ensoli B, Caputo A, Gavioli R, Marconi PC (2014) An attenuated herpes simplex virus type 1 (HSV1) encoding the HIV-1 Tat protein protects mice from a deadly mucosal HSV1 challenge. PLoS One 9:e100844. https:// doi.org/10.1371/journal.pone.0100844

170. Nicoli F, Gallerani E, Skarlis C, Sicurella M, Cafaro A, Ensoli B, Caputo A, Marconi PC, Gavioli R (2016) Systemic immunodominant $\mathrm{CD} 8$ responses with an effector-like phenotype are 
induced by intravaginal immunization with attenuated HSV vectors expressing HIV Tat and mediate protection against HSV infection. Vaccine 34:2216-24. https://doi.org/10.1016/j.vacci ne.2016.03.022

171. Nicoli F, Gallerani E, Sicurella M, Pacifico S, Cafaro A, Ensoli B, Marconi P, Caputo A, Gavioli R (2020) The Tat Protein of HIV-1 Prevents the Loss of HSV-Specific Memory Adaptive Responses and Favors the Control of Viral Reactivation. Vaccines (Basel) 8:274. https://doi.org/10.3390/vaccines8020274

172. Khan AA, Srivastava R, Spencer D, Garg S, Fremgen D, Vahed H, Lopes PP, Pham TT, Hewett C, Kuang J, Ong N, Huang L, Scarfone VM, Nesburn AB, Wechsler SL, BenMohamed L (2015) Phenotypic and functional characterization of herpes simplex virus glycoprotein B epitope-specific effector and memory CD8+ T cells from symptomatic and asymptomatic individuals with ocular herpes. J Virol 89:3776-92. https://doi. org/10.1128/JVI.03419-14

173. Srivastava R, Khan AA, Spencer D, Vahed H, Lopes PP, Thai NT, Wang C, Pham TT, Huang J, Scarfone VM, Nesburn AB, Wechsler SL, BenMohamed L (2015) HLA-A02:01-restricted epitopes identified from the herpes simplex virus tegument protein VP11/12 preferentially recall polyfunctional effector memory CD8+ T cells from seropositive asymptomatic individuals and protect humanized HLA-A*02:01 transgenic mice against ocular herpes. J Immunol 194:2232-48. https://doi.org/ 10.4049/jimmunol.1402606

174. Cafaro A, Piccaro G, Altavilla G, Gigantino V, Matarese G, Olivieri E, Ferrantelli F, Ensoli B, Palma C (2016) HIV-1 Tat protein vaccination in mice infected with Mycobacterium tuberculosis is safe, immunogenic and reduces bacterial lung pathology. BMC Infect Dis 16:442. https://doi.org/10.1186/ s12879-016-1724-7

175. Rezza G, Fiorelli V, Dorrucci M, Ciccozzi M, Tripiciano A, Scoglio A, Collacchi B, Ruiz-Alvarez M, Giannetto C, Caputo A et al (2005) The presence of anti-Tat antibodies is predictive of long-term nonprogression to AIDS or severe immunodeficiency: Findings in a cohort of HIV-1 seroconverters. J Infect Dis 191:1321-1324. https://doi.org/10.1086/428909

176. Re MC, Furlini G, Vignoli M, Ramazzotti E, Roderigo G, De Rosa V, Zauli G, Lolli S, Capitani S, La Placa M (1995) Effect of antibody to HIV-1 Tat protein on viral replication in vitro and progression of HIV-1 disease in vivo. J Acquir Immune Defic Syndr Hum Retrovirol 10:408-416. https://doi.org/10. 1097/00042560-199512000-00003

177. Zagury JF, Sill A, Blattner W, Lachgar A, Le Buanec H, Richardson M, Rappaport J, Hendel H, Bizzini B, Gringeri A et al (1998) Antibodies to the HIV-1 Tat protein correlated with nonprogression to AIDS: A rationale for the use of Tat toxoid as an HIV-1 vaccine. J Hum Virol 1:282-292

178. Re MC, Vignoli M, Furlini G, Gibellini D, Colangeli V, Vitone F, La Placa M (2001) Antibodies against full-length Tat protein and some low-molecular-weight Tat-peptides correlate with low or undetectable viral load in HIV-1 seropositive patients. J Clin Virol 21:81-89. https://doi.org/10.1016/S1386-6532(00) 00189-X

179. Richardson MW, Mirchandani J, Duong J, Grimaldo S, Kocieda V, Hendel H, Khalili K, Zagury JF, Rappaport J (2003) Antibodies to Tat and Vpr in the GRIV cohort: Differential association with maintenance of long-term non-progression status in HIV-1 infection. Biomed Pharmacother 57:4-14. https://doi. org/10.1016/S0753-3322(02)00327-X

180. Bellino S, Tripiciano A, Picconi O, Francavilla V, Longo O, Sgadari C, Paniccia G, Arancio A, Angarano G, Ladisa N et al (2014) The presence of anti-Tat antibodies in HIV-infected individuals is associated with containment of CD4+ T-cell decay and viral load, and with delay of disease progression:
Results of a 3-year cohort study. Retrovirology 11:49. https:// doi.org/10.1186/1742-4690-11-49

181. Cafaro A, Tripiciano A, Sgadari C, Bellino S, Picconi O, Longo O, Francavilla V, Buttò S, Titti F, Monini P et al (2015) Development of a novel AIDS vaccine: The HIV-1 transactivator of transcription protein vaccine. Expert Opin Biol Ther 15:S13-S29. https://doi.org/10.1517/14712598.2015.1021328

182. Cafaro A, Tripiciano A, Picconi O, Sgadari C, Moretti S, Buttò S, Monini P, Ensoli B (2019) Anti-Tat Immunity in HIV-1 Infection: Effects of Naturally Occurring and Vaccine-Induced Antibodies Against Tat on the Course of the Disease. Vaccines (Basel) 7:99. https://doi.org/10.3390/vaccines7030099

183. Kulkarni A, Kurle S, Shete A, Ghate M, Godbole S, Madhavi V, Kent J (2017) Indian Long-term Non-Progressors Show Broad ADCC Responses with Preferential Recognition of V3 Region of Envelope and a Region from Tat Protein. Front Immunol 8:5. https://doi.org/10.3389/fimmu.2017.00005

184. Addo MM, Altfeld M, Rosenberg ES, Eldridge RL, Philips MN, Habeeb K, Khatri A, Brander C, Robbins GK, Mazzara GP et al (2001) HIV Controller Study Collaboration. The HIV-1 regulatory proteins Tat and Rev are frequently targeted by cytotoxic $\mathrm{T}$ lymphocytes derived from HIV-1-infected individuals. Proc Natl Acad Sci USA 98:1781-1786. https://doi.org/10.1073/pnas.98.4. 1781

185. Van Baalen CA, Pontesilli O, Huisman RC, Geretti AM, Klein MR, de Wolf F, Miedema F, Gruters RA, Osterhaus AD (1997) Human immunodeficiency virus type 1 Rev- and Tat-specific cytotoxic $\mathrm{T}$ lymphocyte frequencies inversely correlate with rapid progression to AIDS. J Gen Virol 78:1913-1918. https:// doi.org/10.1099/0022-1317-78-8-1913

186. Jones NA, Wei X, Flower DR, Wong M, Michor F, Saag MS, Hahn BH, Nowak MA, Shaw GM, Borrow P (2004) Determinants of human immunodeficiency virus type 1 escape from the primary CD8+ cytotoxic T lymphocyte response. J Exp Med 200:1243-56. https://doi.org/10.1084/jem.20040511

187. Cao J, McNevin J, Malhotra U et al (2003) Evolution of CD8+ T cell immunity and viral escape following acute HIV-1 infection. J Immunol 171:3837-3846. https://doi.org/10.4049/jimmunol. 171.7.3837

188. Tripiciano A, Picconi O, Moretti S, Sgadari C, Cafaro A, Francavilla V, Arancio A, Paniccia G, Campagna M, Pavone-Cossut MR, Sighinolfi L, Latini A, Mercurio VS, Pietro MD, Castelli F, Saracino A, Mussini C, Perri GD, Galli M, Nozza S, Ensoli F, Monini P, Ensoli B (2021) Anti-Tat immunity defines CD4+ T-cell dynamics in people living with HIV on long-term cART. EBioMedicine 66:103306. https://doi.org/10.1016/j.ebiom.2021. 103306

189. Cafaro A, Caputo A, Fracasso C, Maggiorella MT, Goletti D, Baroncelli S, Pace M, Sernicola L, Koanga-Mogtomo ML, Betti M et al (1999) Control of SHIV-89.6P-infection of cynomolgus monkeys by HIV-1 Tat protein vaccine. Nat Med 5:643-650. https://doi.org/10.1038/9488

190. Cafaro A, Caputo A, Maggiorella MT, Baroncelli S, Fracasso C, Pace M, Borsetti A, Sernicola L, Negri DR, Ten Haaft P et al (2000) SHIV89.6P pathogenicity in cynomolgus monkeys and control of viral replication and disease onset by human immunodeficiency virus type 1 Tat vaccine. J Med Primatol 29:193-208. https://doi.org/10.1034/j.1600-0684.2000.290313.x

191. Cafaro A, Titti F, Fracasso C, Maggiorella MT, Baroncelli S, Caputo A, Goletti D, Borsetti A, Pace M, Fanales-Belasio E et al (2001) Vaccination with DNA containing tat coding sequences and unmethylated $\mathrm{CpG}$ motifs protects cynomolgus monkeys upon infection with simian/human immunodeficiency virus (SHIV89.6P). Vaccine 19:2862-2877. https://doi.org/10.1016/ S0264-410X(01)00002-0 
192. Maggiorella MT, Baroncelli S, Michelini Z, Fanales-Belasio E, Moretti S, Sernicola L, Cara A, Negri DR, Buttò S, Fiorelli V et al (2004) Long-term protection against SHIV89.6P replication in HIV-1 Tat vaccinated cynomolgus monkeys. Vaccine 22:3258-3269. https://doi.org/10.1016/j.vaccine.2004.03.009

193. Borsetti A, Baroncelli S, Maggiorella MT, Moretti S, FanalesBelasio E, Sernicola L, Tripiciano A, Macchia I, Michelini $\mathrm{Z}$, Belli R et al (2009) Containment of infection in tat vaccinated monkeys after rechallenge with a higher dose of SHIV89.6P(cy243). Viral Immunol 22:117-124. https://doi.org/ 10.1089/vim.2008.0082

194. Cafaro A, Bellino S, Titti F, Maggiorella MT, Sernicola L, Wiseman RW, Venzon D, Karl JA, O'Connor D, Monini P et al (2010) Impact of viral dose and major histocompatibility complex class IB haplotype on viral outcome in mauritian cynomolgus monkeys vaccinated with Tat upon challenge with simian/human immunodeficiency virus SHIV89.6P. J Virol 84:8953-8958. https://doi.org/10.1128/JVI.00377-10

195. Demberg T, Florese RH, Heath MJ, Larsen K, Kalisz I, Kalyanaraman VS, Lee EM, Pal R, Venzon D, Grant R et al (2007) A replication-competent adenovirus-human immunodeficiency virus (Ad-HIV) tat and Ad-HIV env priming/Tat and envelope protein boosting regimen elicits enhanced protective efficacy against simian/human immunodeficiency virus SHIV89.6P challenge in rhesus macaques. J Virol 81:3414-3427. https://doi.org/ 10.1128/JVI.02453-06

196. Lakhashe SK, Wang W, Siddappa NB, Hemashettar G, Polacino $\mathrm{P}, \mathrm{Hu}$ SL, Villinger F, Else JG, Novembre FJ, Yoon JK, Lee SJ, Montefiori DC, Ruprecht RM, Rasmussen RA (2011) Vaccination against heterologous R5 clade C SHIV: prevention of infection and correlates of protection. PLoS One 6:e22010. https:// doi.org/10.1371/journal.pone.0022010

197. Bachler BC, Humbert M, Palikuqi B, Siddappa NB, Lakhashe SK, Rasmussen RA, Ruprecht RM (2013) Novel biopanning strategy to identify epitopes associated with vaccine protection. J Virol 87:4403-4416. https://doi.org/10.1128/JVI.02888-12

198. Ensoli B, Fiorelli V, Ensoli F, Lazzarin A, Visintini R, Narciso P, Di Carlo A, Monini P, Magnani M, Garaci E (2008) The therapeutic phase I trial of the recombinant native HIV-1 Tat protein. AIDS 22:2207-2209. https://doi.org/10.1097/QAD.0b013e3283 $1392 \mathrm{~d} 4$

199. Ensoli B, Fiorelli V, Ensoli F, Lazzarin A, Visintini R, Narciso P, Di Carlo A, Tripiciano A, Longo O, Bellino S et al (2009) The preventive phase I trial with the HIV-1 Tat-based vaccine. Vaccine 28:371-378. https://doi.org/10.1016/j.vaccine.2009.10. 038

200. Bellino S, Francavilla V, Longo O, Tripiciano A, Paniccia G, Arancio A, Fiorelli V, Scoglio A, Collacchi B, Campagna M et al (2009) Parallel conduction of the phase I preventive and therapeutic trials based on the Tat vaccine candidate. Rev Recent Clin Trials 4:195-204. https://doi.org/10.2174/157488709789957529

201. Ensoli B, Cafaro A, Monini P, Marcotullio S, Ensoli F (2014) Challenges in HIV vaccine research for treatment and prevention. Front Immunol 5:417. https://doi.org/10.3389/fimmu.2014.00417

202. Sgadari C, Monini P, Tripiciano A, Picconi O, Casabianca A, Orlandi C, Moretti S, Francavilla V, Arancio A, Paniccia G et al (2019) Continued Decay of HIV Proviral DNA Upon Vaccination With HIV-1 Tat of Subjects on Long-Term ART: An 8-Year Follow-Up Study. Front Immunol 10:233. https://doi.org/10. 3389/fimmu.2019.00233
203. Ensoli B, Nchabeleng M, Ensoli F, Tripiciano A, Bellino S, Picconi O, Sgadari C, Longo O, Tavoschi L, Joffe D, SMU-MeCRU study group et al (2016) HIV-Tat immunization induces crossclade neutralizing antibodies and CD4(+) $\mathrm{T}$ cell increases in antiretroviral-treated South African volunteers: A randomized phase II clinical trial. Retrovirology 13:34. https://doi.org/10. 1186/s12977-016-0261-1

204. Rosás-Umbert M, Mothe B, Noguera-Julian M, Bellido R, Puertas MC, Carrillo J, Rodriguez C, Perez-Alvarez N, Cobarsí P, Gomez CE, Esteban M, Jímenez JL, García F, Blanco J, Martinez-Picado J, Paredes R, Brander C (2017) Virological and immunological outcome of treatment interruption in HIV-1-infected subjects vaccinated with MVA-B. PLoS One 12(9):e0184929. https://doi.org/10.1371/journal.pone.0184929

205. Sharaf R, Lee GQ, Sun X, Etemad B, Aboukhater LM, Hu Z, Brumme ZL, Aga E, Bosch RJ, Wen Y, Namazi G, Gao C, Acosta EP, Gandhi RT, Jacobson JM, Skiest D, Margolis DM, Mitsuyasu R, Volberding P, Connick E, Kuritzkes DR, Lederman MM, Yu XG, Lichterfeld M, Li JZ (2018) HIV-1 proviral landscapes distinguish posttreatment controllers from noncontrollers. J Clin Invest 128(9):4074-4085. https://doi.org/10.1172/JCI12 0549

206. Clumeck N, Hermans P, Zagury D, Le Buanec H, Burny A, Bizzini B, Gilliam B, Redfield R, Gallo R (2006) Neutralizing anti-Tat antibodies prolonged HAART interruption in vaccines in a prospective structured interruption study. Retrovirology 3(Suppl 1):S15. https://doi.org/10.1186/1742-4690-3-S1-S15

207. Loret EP, Darque A, Jouve E, Loret EA, Nicolino-Brunet C, Morange S, Castanier E, Casanova J, Caloustian C, Bornet C, Coussirou J, Boussetta J, Couallier V, Blin O, Dussol B, Ravaux I (2016) Intradermal injection of a Tat Oyi-based therapeutic HIV vaccine reduces of $1.5 \log$ copies/mL the HIV RNA rebound median and no HIV DNA rebound following cART interruption in a phase I/II randomized controlled clinical trial. Retrovirology 13:21. https://doi.org/10.1186/s12977-016-0251-3

208. Gruell H, Klein F (2018) Antibody-mediated prevention and treatment of HIV-1 infection. Retrovirology 15(1):73. https:// doi.org/10.1186/s12977-018-0455-9

209. Brake DA, Goudsmit J, Krone WJ, Schammel P, Appleby N, Meloen RH, Debouck C (1990) Characterization of murine monoclonal antibodies to the tat protein from human immunodeficiency virus type 1. J Virol 64(2):962-5. https://doi.org/10. 1128/JVI.64.2.962-965.1990

210. Moreau E, Hoebeke J, Zagury D, Muller S, Desgranges C (2004) Generation and characterization of neutralizing human monoclonal antibodies against human immunodeficiency virus type 1 Tat antigen. J Virol 78(7):3792-6. https://doi.org/10.1128/jvi.78.7. 3792-3796.2004

211. Mediouni S, Watkins JD, Pierres M, Bole A, Loret EP, Baillat $G$ (2012) A monoclonal antibody directed against a conformational epitope of the HIV-1 trans-activator (Tat) protein neutralizes cross-clade. J Biol Chem 287(15):11942-50. https://doi.org/ 10.1074/jbc.M111.319863

Publisher's Note Springer Nature remains neutral with regard to jurisdictional claims in published maps and institutional affiliations. 